\title{
Monsoon-forced chlorophyll distribution and primary production in the South China Sea: observations and a numerical study
}

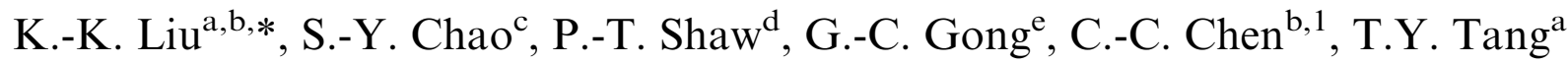 \\ ${ }^{a}$ Institute of Oceanography, National Taiwan University, Taipei 106, Taiwan, Republic of China \\ ${ }^{\mathrm{b}}$ National Center for Ocean Research, P.O. Box 23-13, Taipei 106, Taiwan, Republic of China \\ ${ }^{\mathrm{c}}$ Horn Point Laboratory, University of Maryland Center for Environmental Science, Cambridge, MD 21613-0775, USA \\ d Department of Marine Earth and Atmospheric Sciences, North Carolina State University, Raleigh, NC 27695-8208, USA \\ ${ }^{\mathrm{e}}$ Department of Oceanography, National Taiwan Ocean University, Keelung 202, Taiwan, Republic of China
}

Received 2 May 2001; received in revised form 27 December 2001; accepted 8 May 2002

\begin{abstract}
Although the South China Sea (SCS) exchanges water constantly with the western Philippine Sea, its nutricline is much shallower and its chlorophyll level in surface waters is twice as high. Analysis of CZCS-SeaWiFS data and shipboard data reveals a strong seasonality of chlorophyll in the SCS in three upwelling regions. A three-dimensional numerical model with coupled physics and biogeochemistry is developed to study the effect of monsoonal forcing on nutrient upwelling and phytoplankton growth in the SCS. The model has a horizontal resolution of $0.4^{\circ}$ in the domain $2-24.8^{\circ} \mathrm{N}$ and $99-124.6^{\circ} \mathrm{E}$ and 21 layers in the vertical. The circulation is driven by monthly climatological winds. The nitrogen-based ecosystem model has four compartments: dissolved inorganic nitrogen (DIN), phytoplankton, zooplankton and detritus. The chlorophyll-to-phytoplankton ratio depends on light and DIN availability. The biological equations and parameters are taken from previous modeling studies of the Sargasso Sea. The model simulates the nitrate profile, the strong subsurface chlorophyll maximum, and the primary production in the central basin with reasonable success. It also generates intense chlorophyll patches in the monsoon-driven upwelling regions northwest of Luzon and north of the Sunda Shelf in winter and off the east coast of Vietnam in summer. The results are in reasonable agreement with shipboard observations and CZCS-SeaWiFS data. The primary production derived from SeaWiFS data shows a strong peak in winter and weak peak in summer with an annual mean of $354 \mathrm{mg} \mathrm{C} \mathrm{m}^{-2} \mathrm{~d}^{-1}$ for the whole basin. The modeled primary production displays seasonal variation resembling the trend derived from SeaWiFS data, but the magnitude $\left(280 \mathrm{mg} \mathrm{C} \mathrm{m}^{-2} \mathrm{~d}^{-1}\right)$ is smaller by $20 \%$. The model also predicts an export fraction of $12 \%$ from the primary production in the euphotic zone. (C) 2002 Elsevier Science Ltd. All rights reserved.
\end{abstract}

Keywords: South China Sea; Monsoons; Upwelling; Chlorophyll; Primary production; Modeling

*Corresponding author. Institute of Oceanography, National Taiwan University, Taipei 106, Taiwan, Republic of China. Fax: + 886-2-2363-1810.

E-mail address: kkliu@ccms.ntu.edu.tw (K.-K. Liu).

${ }^{1}$ Now at: Dept. of Biology, National Taiwan Normal University, Taipei, Taiwan 106, Republic of China.

\section{Introduction}

The South China Sea (SCS), extending from the equator to $23^{\circ} \mathrm{N}$ and from $99^{\circ} \mathrm{E}$ to $121^{\circ} \mathrm{E}$ (see Fig. 1), is the largest marginal sea in southeast 


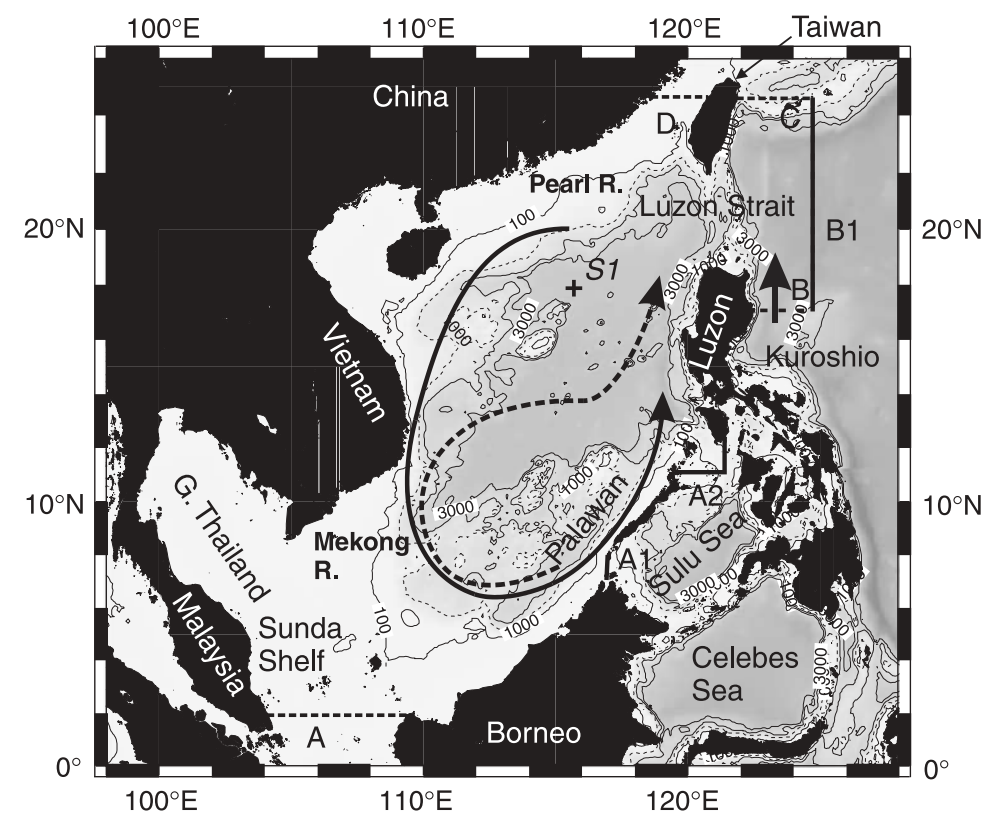

Fig. 1. Map, with isobaths (in meters), of the SCS. The solid and the dashed curves with arrows indicate the winter and summer jets, respectively. The heavy solid and dashed lines represent closed and open ocean boundaries of the model domain, respectively. Site S1 $\left(18^{\circ} \mathrm{N}, 116^{\circ} \mathrm{E}\right)$ as indicated by the cross $(+)$ in the northern SCS is a time-series station (SEATS).

Asia and second in area only to the ice-covered Arctic Sea in the world ocean (Sverdrup et al., 1942). It has wide continental shelves to the northwest and south, voluminous runoff from several large rivers such as the Mekong River and the Pearl River, and a deep basin reaching $4700 \mathrm{~m}$ deep. The basin is connected to the open ocean through several passages between the surrounding landmasses and islands, but the Luzon Strait (sill depth $\sim 1900 \mathrm{~m}$ ) is the only major channel allowing effective water exchange with the western North Pacific. On a larger geographic scale, it is located between two major climate driving engines on earth, the western Pacific warm pool to the east and the Tibet Plateau to the northwest.

Climatic variations in the atmosphere and in the upper ocean of the SCS are primarily controlled by the East Asian monsoon, which follows closely the climatic variations in the equatorial central Pacific. The southwest (summer) monsoon lasts from June to September. The stronger northeast (winter) monsoon appears from November to March and is known to vary with the Southern Oscillation Index
(Zhang et al., 1997). The extremely high seasurface temperature in the central basin in spring $\left(>29^{\circ} \mathrm{C}\right.$ ) produces a large heat flux to the atmosphere; the climatological outgoing longwave radiation exceeds $230 \mathrm{~W} \mathrm{~m}^{-2}$ at the onset of the summer monsoon in the SCS (Ose et al., 1997). The sea-surface temperature anomaly in summer correlates well with the equatorial sea-surface temperature anomalies in the preceding winter and has been suggested as an indicator for the monsoonal variations and El Niño and southern oscillation (ENSO) (Ose et al., 1997). In the deep basin, the Pacific water entering the basin through the Luzon Strait becomes the deep-water mass of the SCS (Nitani, 1972; Broecker et al., 1986). A fairly short residence time of 50-150 years has been suggested for the deep water in the basin (Broecker et al., 1986; Gong et al., 1992). The deep water upwells and mixes with surface waters to form the intermediate water (Gong et al., 1992), which flows out of the Luzon Strait and modifies the water properties along the western edge of the Kuroshio. Water from the SCS can be traced 
along the Kuroshio as far north as the Okinawa Trough (Chen and Wang, 1998).

The upwelling of the deep water brings the nutrient-laden water closer to the surface. Gong et al. (1992) demonstrated that the nutricline in the SCS could be uplifted by as much as $100 \mathrm{~m}$ in comparison with that in the western Philippine Sea. Chen and Wang (1998) suggested that the outflow of intermediate water through the Luzon Strait may be an important nutrient source for the Kuroshio. Away from the coastal zone, the mean CZCS pigment concentration in the SCS proper is $0.10 \mathrm{mg} \mathrm{m}^{-3}$, which is about twice the value in the western Philippine Sea. The relative enrichment of phytoplankton in the SCS is apparently related to the uplifted nutricline, but the coupled physicalbiogeochemical processes responsible for such enrichment are yet to be investigated. Monsoonal forcing is probably a major driving force.

The surface circulation in the SCS changes drastically with season in response to the alternating monsoons. The winter monsoon forces a cyclonic gyre (Fig. 1) covering the entire deep basin with an intensified southward jet along the coast of Vietnam (Wyrtki, 1961; Shaw and Chao, 1994). The summer monsoon drives an anticyclonic gyre mainly in the southern basin. The summer coastal jet (Fig. 1) separates from the coast of Vietnam at around $12^{\circ} \mathrm{N}$ and flows toward the Luzon Strait. Localized upwelling is forced by the circulation gyres in areas off Vietnam during the summer monsoon and off the Sunda Shelf and western Luzon during the winter monsoon (Chao et al., 1996a; Shaw et al., 1996; Udarbe-Walker and Villanoy, 2001).

Inter-annual variations in the SCS are mostly associated with weakened circulation gyres and upwelling under weakened monsoons during El Niño (Chao et al., 1996b; Wu et al., 1999). On a longer time scale, paleoceanographic variations in the foraminiferal and geochemical records during past glacial-inter-glacial cycles have also been attributed to climate changes manifested by variations in monsoon strengths (e.g., Wang et al., 1995, 1999; Wang and Wang, 1990). Variability in sedimentary organic carbon content has been interpreted as evidence for changes in biological production, which was in turn linked to changes in the monsoon strengths (e.g., Huang et al., 1997). The responsiveness of the SCS to the monsoons has inspired a recent boom in sampling of the SCS sediments for paleoceanographic studies (Chen et al., 1998; Prell et al., 1999).

It is conceivable that the biogeochemistry of the SCS could respond to the alternating monsoons in a way similar to the monsoon-driven Arabian Sea biogeochemistry (Smith et al., 1998; Burkill, 1999). For example, Tang et al. (1999) attributed the recurrence of a winter phytoplankton bloom off northwest Luzon, revealed in the coastal zone color scanner (CZCS) data, to upwelling under the northeast monsoon (Shaw et al., 1996; UdarbeWalker and Villanoy, 2001). However, unlike the Arabian Sea, the SCS has received relatively little attention in the biogeochemical research. Under the influence of two nearby climate driving engines, the SCS would be an ideal site to study the sensitivity of physical and biogeochemical conditions to climate changes.

To address the biogeochemical responses to climate changes in the SCS, we need first to delineate how the system works under modern physical forcing. The purpose of this study is to provide observational data that characterize the biogeochemical features of the SCS and to develop a numerical model with coupled physical and biogeochemical processes to simulate the seasonal and spatial variability of chlorophyll and primary production under monsoonal forcing. Model results will be used to guide newly launched SCS field studies (Shiah et al., 1999), including South-East Asia Time-series Station (SEATS) and SCS-Integrated Biogeochemical Experiment (SIBEX).

\section{Description of the model and observations}

\subsection{Hydrodynamic model}

The hydrodynamic model has been described in the papers of Shaw and Chao (1994) and Chao et al. (1996a). It has a horizontal resolution of $0.4^{\circ}$ in the domain $99-124.6^{\circ} \mathrm{E}$ and $2-25.6^{\circ} \mathrm{N}$. In the vertical direction, the model has 21 layers with variable thickness. Variables are evaluated at the 
center of each layer at 2.5, 10, 20,30, 50,75, 100, $125,150,200,300,500,700,900,1200,1500,2000$, $2500,3000,4000$, and $5000 \mathrm{~m}$ beneath sea surface. These depths are chosen to be as close to the standard depths adopted by National Oceanographic Data Center (NODC, USA) as possible for easy implementation of initial temperature and salinity. The model solves the three-dimensional primitive equations with Boussinesq and hydrostatic approximations. It is similar to the general circulation model of Semtner (1974) except for the addition of a free sea surface and split time steps for internal and external modes. Time steps for computing the internal mode and the external mode are 2160 and $21.6 \mathrm{~s}$, respectively. The horizontal diffusivity is $2 \times 10^{8} \mathrm{~cm}^{2} \mathrm{~s}^{-1}$.

Open boundaries, marked by dashed lines (A, B, C, and D) in Fig. 1, are at the Sunda Shelf, east of the Luzon Strait, and the Taiwan Strait. Solid lines (A1, A2 and B1) indicate closed ocean boundaries. Flow exchange between the SCS and the Sulu Sea is relatively small (Wyrtki, 1961), justifying the closing of boundaries A1 and A2. Furthermore, since the Kuroshio flow is essentially northward (from boundary B to boundary C), zonal exchange with the Pacific Ocean is truncated by placing a vertical wall along B1. Open boundary conditions for the external-mode velocity normal to the boundary $(U)$ are given by the prescribed transport estimates of Wyrtki (1961). After being initialized by the January temperature and salinity fields of Levitus (1982), the model is driven by climatological monthly mean wind, monthly seasurface temperature, and seasonal surface salinity. The flow field in the third year of the model run shows little change from those in the previous years (Shaw and Chao, 1994).

\subsection{Biogeochemical model}

The biogeochemical model is linked to the physical model with the same spatial and temporal resolution. The time-dependent change of a biogeochemical tracer $\left(C_{i}\right)$ is governed by the following equation:

$$
\frac{\partial C_{i}}{\partial t}=\vec{\nabla}\left(A \vec{\nabla} C_{i}\right)-\vec{V} \cdot \vec{\nabla} C_{i}+J_{i},
$$

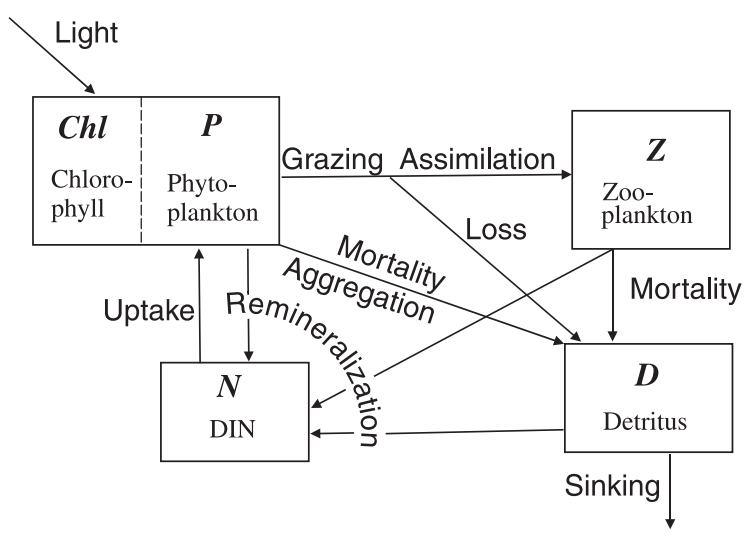

Fig. 2. A schematic of the nitrogen-based biogeochemical model.

where $A$ is the diffusion, vector $V$ is the velocity and $J_{i}$ is production minus consumption.

Since pelagic ecosystem studies in the SCS are scarce, the biogeochemical model that governs the interaction among the biogeochemical tracers is kept to a rather simpler form (Fig. 2). It contains four compartments, dissolved inorganic nitrogen (DIN or simply $N$ when used in mathematical equations), phytoplankton $(P)$, zooplankton $(Z)$ and detritus $(D)$, with a variable chlorophyll $(\mathrm{Chl})$ to-phytoplankton ratio. Chlorophyll is expressed in units of $\mathrm{mg} \mathrm{m}^{-3}$. All other biogeochemical state variables are expressed in terms of nitrogen concentration $\left(\mu \mathrm{M}\right.$ or mmol $\mathrm{N} \mathrm{m}^{-3}$ ). The biogeochemical parameters are listed in Table 1.

All mathematical expressions for biogeochemical processes are taken from Doney et al. (1996) except those for grazing and zooplankton mortality. The latter expressions are adopted from McGillicuddy et al. (1995). The governing equations follow Evans and Garcon (1997). The $J$-term for $P$ is

$$
\begin{aligned}
J_{P}= & \mu_{P} P\left[1-\exp \left(-\frac{\alpha R_{H i E} E}{\mu_{P}}\right)\right] \frac{R}{R_{H i E}} \frac{N}{N+\kappa_{N}} \\
& -\eta P-\omega P^{2}-\mu_{Z} Z[1-\exp (-\lambda P)] .
\end{aligned}
$$

The term $E$, to be expressed in mathematical terms later, is the photosynthetically active radiation in units of $\mathrm{W} \mathrm{m}^{-2}$. On the right-hand side of Eq. (2), the four terms represent phytoplankton growth, 
Table 1

Biogeochemical parameter values

\begin{tabular}{|c|c|c|c|c|}
\hline Parameters & Description & Units & Value & References \\
\hline$\kappa_{\mathrm{c}}$ & Light attenuation due to chlorophyll & $\left(\mathrm{mg} \mathrm{Chl} \mathrm{m}{ }^{-2}\right)^{-1}$ & 0.048 & Fasham et al. (1990) \\
\hline$\kappa_{\mathrm{w}}$ & Light attenuation due to water & $\mathrm{M}^{-1}$ & 0.040 & Fasham et al. (1990) \\
\hline$q_{10}$ & Temperature dependent growth rate & & 1.884 & Doney et al. (1996) \\
\hline$\mu_{P 20}$ & $\begin{array}{l}\text { Maximum specific growth rate of } \\
\text { phytoplankton at } 20^{\circ} \mathrm{C}\end{array}$ & $\mathrm{d}^{-1}$ & 2.10 & Doney et al. (1996) \\
\hline$\alpha$ & Initial slope of $P-E$ curve & $\begin{array}{l}(\mathrm{mmol} \mathrm{N} / \mathrm{mg} \mathrm{Chl}) \mathrm{d}^{-1} \\
\left(\mathrm{~W} \mathrm{~m}^{-2}\right)^{-1}\end{array}$ & 0.050 & Doney et al. (1996) \\
\hline$\kappa_{N}$ & DIN half saturation concentration & $\mathrm{Mmol} \mathrm{Nm} \mathrm{N}^{-3}$ & 0.20 & Doney et al. (1996) \\
\hline$R_{H}$ & $\begin{array}{l}\text { Minimum chlorophyll/phytoplankton ratio } \\
\text { (for high-light condition) }\end{array}$ & $\operatorname{Mg~Chl~}(\mathrm{mmol} \mathrm{N})^{-1}$ & 1.0 & Doney et al. (1996) \\
\hline$R_{L}$ & $\begin{array}{l}\text { Maximum chlorophyll/phytoplankton ratio } \\
\text { (for low-light condition) }\end{array}$ & $\operatorname{MgChl}(\operatorname{mmol~N})^{-1}$ & 2.5 & Doney et al. (1996) \\
\hline$E_{K}$ & Light level where photoadaptation starts & $\mathrm{W} \mathrm{m}^{-2}$ & 90 & Doney et al. (1996) \\
\hline$\eta$ & Phytoplankton mortality rate constant & $\mathrm{d}^{-1}$ & 0.075 & Doney et al. (1996) \\
\hline$\omega$ & Phytoplankton aggregation rate constant & $\left(\mathrm{mmol} \mathrm{Nm} \mathrm{m}^{-3}\right)^{-1} \mathrm{~d}^{-1}$ & 0.10 & Doney et al. (1996) \\
\hline$\mu_{Z 20}$ & $\begin{array}{l}\text { Maximum specific growth rate of zooplankton } \\
\text { at } 20^{\circ} \mathrm{C}\end{array}$ & $d^{-1}$ & 1.0 & Fasham et al. (1990) \\
\hline$\lambda$ & Ivlev grazing constant & $\left(\mathrm{mmol} \mathrm{N} \mathrm{m}{ }^{-3}\right)^{-1}$ & 1.0 & $\begin{array}{l}\text { McGillicuddy et al. } \\
\text { (1995) }\end{array}$ \\
\hline$\gamma$ & Fraction of grazing loss & & 0.25 & $\begin{array}{l}\text { McGillicuddy et al. } \\
\text { (1995) }\end{array}$ \\
\hline$n_{1}$ & Linear zooplankton mortality rate constant & $\mathrm{d}^{-1}$ & 0.11 & $\begin{array}{l}\text { McGillicuddy et al. } \\
\text { (1995) }\end{array}$ \\
\hline$n_{2}$ & Quadratic zooplankton mortality rate constant & $\left.(\mathrm{mmol} \mathrm{N} \mathrm{m})^{-3}\right)^{-1} \mathrm{~d}^{-1}$ & 0.52 & $\begin{array}{l}\text { McGillicuddy et al. } \\
\text { (1995) }\end{array}$ \\
\hline$\varepsilon_{1}$ & $\begin{array}{l}\text { Fraction of linear rate of zooplankton loss that } \\
\text { turns into to detritus }\end{array}$ & & 0.75 & $\begin{array}{l}\text { McGillicuddy et al. } \\
\text { (1995) }\end{array}$ \\
\hline$\varepsilon_{2}$ & $\begin{array}{l}\text { Fraction of quadratic rate of zooplankton loss } \\
\text { that turns into to detritus }\end{array}$ & & 0.50 & $\begin{array}{l}\text { McGillicuddy et al. } \\
\text { (1995) }\end{array}$ \\
\hline$\delta$ & Remineralization rate constant of detritus & $\mathrm{d}^{-1}$ & 0.10 & Doney et al. (1996) \\
\hline$w_{\text {sink }}$ & Vertical velocity of detritus relative to water & $\mathrm{Md}^{-1}$ & -10 & Doney et al. (1996) \\
\hline
\end{tabular}

mortality, aggregation and zooplankton grazing. The maximum specific growth rates of phytoplankton $\left(\mu_{P}\right)$ and zooplankton $\left(\mu_{Z}\right)$ depend on temperature $\left(T\right.$ in $\left.{ }^{\circ} \mathrm{C}\right)$ as follows:

$\mu=\mu_{20} q_{10}^{(T-20) / 10}$.

In the growth term, the time-rate of change of the chlorophyll-to-phytoplankton ratio, $R=\mathrm{Chl} / P$, is dependent on light and DIN availability:

$$
\begin{aligned}
\frac{\partial R}{\partial t}= & \mu_{P}\left[1-\exp \left(-\frac{\alpha R_{\mathrm{H}} E}{\mu_{P}}\right)\right] \frac{R}{R_{\mathrm{H}}} \\
& \times\left\{\frac{N}{N+\kappa_{N}}\left[R_{\mathrm{L}}-(\Delta R) \min \left(\frac{E}{E_{k}}, 1\right)\right]-R\right\},
\end{aligned}
$$

where $\Delta R=R_{\mathrm{L}}-R_{\mathrm{H}}$. The variable chlorophyllto-phytoplankton ratio accounts for photoadaptation of phytoplankton, which is especially important for the rather deep and prominent subsurface chlorophyll maximum (SCM) widely found in tropical and subtropical waters (Furuya, 1990). The extreme values of $R$ for the high-light $\left(R_{\mathrm{H}}\right)$ and low-light $\left(R_{\mathrm{L}}\right)$ conditions are assumed to be 1.0 and $2.5 \mathrm{mg} \mathrm{Chl}(\mathrm{mmol} \mathrm{N})^{-1}$, respectively (Doney et al., 1996). The $J$-term for $Z$ contains an assimilation term and two removal terms for zooplankton mortality:

$J_{Z}=(1-\gamma) \mu_{Z} Z[1-\exp (-\lambda P)]-n_{1} Z-n_{2} Z^{2}$.

The $J$-term for $D$ includes source terms for phytoplankton aggregation, grazing loss, and 
zooplankton mortality, and a removal term for detritus remineralization:

$$
\begin{aligned}
J_{D}= & \omega P^{2}+\gamma \mu_{Z} Z[1-\exp (-\lambda P)] \\
& +\varepsilon_{1} n_{1} Z+\varepsilon_{2} n_{2} Z^{2}-\delta D .
\end{aligned}
$$

For the calculation of the detritus concentration change during each time step by advection and diffusion, the vertical velocity of detritus $\left(W_{D}\right)$ is the sum of the vertical velocity of water parcel and the vertical velocity of detritus relative to water $\left(W_{\text {sink }}\right)$, which is assumed to be $-10 \mathrm{~m} \mathrm{~d}^{-1}$. As the detritus reaches the seafloor, it is assumed to be lost from the system. The $J$-term for $N$ involves all remineralization terms and the removal by phytoplankton uptake:

$$
\begin{aligned}
J_{N}= & \eta P+\left(1-\varepsilon_{1}\right) n_{1} Z+\left(1-\varepsilon_{2}\right) n_{2} Z^{2}+\delta D \\
& -\mu_{P} P\left[1-\exp \left(-\frac{\alpha R_{\mathrm{H}} E}{\mu_{P}}\right)\right] \frac{R}{R_{\mathrm{H}}} \frac{N}{N+\kappa_{N}} .
\end{aligned}
$$

The solar irradiance $\left(\mathrm{W} \mathrm{m}^{-2}\right)$ at the sea surface is calculated by the following equation (Bernhardt and Philippes, 1958):

$E_{\mathrm{s}}=(1-c) \frac{E_{0}}{\rho^{2}} \cos \theta\left[\frac{0.907}{(\cos \theta)^{0.018}}\right]^{\tau / \cos \theta}$,

where $c$ is the fraction of cloud coverage, $E_{0}$ is the solar constant, $\rho$ is the variation of the sun-earth distance, $\theta$ is the zenith angle, and

$\tau=1.40+0.136 q$,

where $q$ is the specific humidity $\left(\mathrm{g} \mathrm{kg}^{-1}\right)$ at the sea surface. The photosynthetically active radiation $\left(\mathrm{W} \mathrm{m}^{-2}\right)$ in the water column follows Bannister (1974):

$E(z)=E_{\mathrm{s}} \exp \left[-\kappa_{\mathrm{w}} z+\kappa_{\mathrm{c}} I_{\mathrm{chl}}(z)\right]$,

where $I_{\mathrm{chl}}(z)$ is the depth-integrated chlorophyll $\left(\mathrm{mg} \mathrm{m}^{-2}\right)$.

Most of the biogeochemical parameter values (Table 1) are the same as those used by Doney et al. (1996). Since we adopt the scheme of McGillicuddy et al. (1995) for zooplankton-related processes, we also use their parameter values except the maximum specific zooplankton growth rate $\left(\mu_{Z}\right)$. Values as high as $5 \mathrm{~d}^{-1}$ have been used for $\mu_{Z}$ in the tropical ocean (Loukos et al., 1997). Since the SCS is in the tropical-subtropical region, we pick a value of $1 \mathrm{~d}^{-1}$ at the temperature of $20^{\circ} \mathrm{C}$ (Fasham et al., 1990). This value is slightly higher than that $\left(0.69 \mathrm{~d}^{-1}\right)$ used by McGillicuddy et al. (1995). Note that the model includes temperature adjustment for growth rates following Doney et al. (1996). At the highest temperature of $30^{\circ} \mathrm{C}$ in the SCS, the maximum specific zooplankton growth rate would be $1.88 \mathrm{~d}^{-1}$, which is still considerably lower than that used by Loukos et al. (1997). The light attenuation factors are taken from Fasham et al. (1990). The attenuation factor due to phytoplankton $\left(\kappa_{\mathrm{c}}\right)$ is converted to a chlorophyll-based value by the chlorophyll/phytoplankton ratio of 1.59 (mg Chl/mmol N).

\subsection{Initial and boundary conditions and model computation: the biogeochemical components}

The initial condition of DIN distribution was obtained by interpolating the annual mean field of nitrate of $1^{\circ}$ resolution from the World Ocean Atlas (WOA-94) CD-ROM (Conkright et al., 1994) provided by the NODC to fit the model grid. The annual mean field of CZCS-derived chlorophyll was used as the initial surface chlorophyll distribution (Feldman et al., 1989). The vertical profile of chlorophyll was assumed to be the same as the Eumali initial profile (Evans and Garçon, 1997), which was obtained from the web site http://ads.smr.uib.no/jgofs/inventory/Toulouse/index.htm. The initial phytoplankton field was calculated from the chlorophyll field under the assumption of a chlorophyll/phytoplankton ratio of 1.59. The initial fields of zooplankton and detritus were calculated from the phytoplankton field under the assumption of constant ratios of $1 / 10$ for zooplankton/phytoplankton and 1/1.42 for detritus/ phytoplankton, which were similar to the Eumali initial conditions for zooplankton and large detritus, respectively (Evans and Garçon, 1997).

Near land boundaries, nitrogen input from river runoff was included in the form of diffusive fluxes (Chao et al., 1992). The runoff data were obtained from Milliman et al. (1995); Kalnay et al. (1996); Wolanski et al. (1996); Zhang (1996) and Global Runoff Data Center (http://www.cais.com/gewex/ grdc.html). The monthly runoff inputs were either taken from available data or calculated from the 
annual mean runoff under the assumption that runoff is proportional to the mean monthly precipitation. The concentrations of DIN in runoff from the Chinese rivers, ranging from 60 to $90 \mu \mathrm{M}$, were taken from Zhang (1996). The concentrations were assumed to be $60 \mu \mathrm{M}$ for the Indochina rivers and $40 \mu \mathrm{M}$ for other rivers.

For the model computation, advection of biogeochemical tracers was calculated by the upstream-differencing scheme to avoid generation of negative concentrations in regions of extreme concentration gradients (Torrance and Rockett, 1969; Sarmiento et al., 1993). The horizontal diffusivity of $4 \times 10^{6} \mathrm{~cm}^{2} \mathrm{~s}^{-1}(1 / 50$ of that for $\mathrm{T}$, $\mathrm{S}$ and momentum) was used in Eq. (1) for the biogeochemical tracers. Equations of biogeochemical processes were solved for the top 10 layers $(0-235 \mathrm{~m})$. The calculation of photosynthetically active radiation, which is dependent on the zenith angle, was carried out for each time step at each grid point. The monthly mean fields of cloud coverage and specific humidity averaged over the period of 1990-1996 (Kalnay et al., 1996) were used to calculate light availability. The coupled model was run for 3 years.

For all biogeochemical variables other than DIN, boundary values on ocean boundaries remain fixed at their initial values throughout the simulation period. For DIN, boundary conditions are derived from temperature data and observed temperature-nitrate relationships in the western Philippine Sea and the SCS (Gong et al., 1992; Yang, 1995) in order to reflect the more realistic conditions. Biogeochemical concentrations in the model interior are insensitive to boundary-imposed values for all variables except DIN, because all other biogeochemical tracers are low in concentration and, therefore, have little effect on the model results.

At every ocean boundary, a buffer zone of $1.2^{\circ}$ was set up for the calculated concentrations of the biogeochemical tracers to relax towards the boundary-imposed values; i.e., at every internal time step of integration, $10 \%$ of the newly computed biogeochemical variables inside the buffer zone is replaced by the boundary value to avoid excessive deviations from boundary values due to the artificiality of the boundaries. This is especially important for the DIN computation. Upwelling may be generated as an artifact on artificial boundaries of the model (Sarmiento et al., 1993). If observed profiles of DIN are not enforced near all boundaries, the artificial upwelling may cause significant increase of DIN concentration in the surface layer, leading to unrealistically high chlorophyll concentration. For Boundaries A1 and A2 (Fig. 1), which separate the SCS and the Sulu Sea, the buffer zones are set as elongated zones towards the Sulu Sea. For other boundaries, the buffer zones are within the model domain. Results for the buffer zones are excluded from presentation and discussion.

\subsection{Observational data}

The monthly composites of sea-surface pigment concentrations derived from the Nimbus-7 CZCS data averaged over the years between 1979 and 1986 (Feldman et al., 1989) were taken from the web site http://seawifs.gsfc.nasa.gov/SEAWIFS/ IMAGES/CZCS_DATA.html. CZCS data are missing in many areas in this region in summer, apparently because of the high cloud coverage. Fortunately, in recent years, the Sea-viewing Wide Field of View Sensor (SeaWiFS) has provided data for the derivation of surface ocean chlorophyll concentrations. For the months from July to September, we obtained the monthly composite version 3 data of SeaWiFS chlorophyll concentrations in August 2001 from NASA. The data are Level 3b Global Area Coverage monthly average chlorophyll $a$ data processed by the OC4 algorithm of SeaDAS.

Observed nitrate and chlorophyll distributions were taken from cruises in the SCS. Cruise 311 was aboard R/V Ocean Researcher I (OR-I) from 12 to 26 March 1992. Cruise 468 (from 14 to 18 September 1998) and Cruise 500 (from 22 to 27 January 1999) were aboard Ocean Researcher III (OR-III). Primary production was measured at six stations in the northern SCS during 1-12 March 2000 on Cruise 575 aboard OR-I. Chlorophyll data were obtained at Site $\mathrm{S} 1\left(18^{\circ} \mathrm{N}, 116^{\circ} \mathrm{E}\right)$, which is a time-series station of SEATS, on Cruise 484 (15-16 April 1997) aboard OR-I and on six 
additional cruises between September 1999 and July 2000 aboard OR-II.

Seawater samples were collected with a Rosette sampler (General Oceanic Inc., USA) with Tefloncoated Go-Flo bottles (General Oceanic Inc., USA) mounted on the CTD assembly. Water samples for nutrient measurements were placed in $100 \mathrm{ml}$ polypropylene bottles and frozen immediately with liquid nitrogen. Nitrate was analyzed with a self-designed flow injection analyzer and was reduced to nitrite with a cadmium wire which was activated with copper sulfate solution (Gong, 1992). The precision for the nitrate analysis was $0.3 \mu \mathrm{M}$ for concentrations of $10 \mu \mathrm{M}$ or higher. Water samples for chlorophyll analysis were immediately filtered through GF/F filters (Whatman, $47 \mathrm{~mm}$ ), which were stored at $-20^{\circ} \mathrm{C}$. Chlorophyll retained on $\mathrm{GF} / \mathrm{F}$ filters was determined fluorometrically (Strickland and Parsons, 1972; Gong et al., 1993). The GF/F filters were ground in $10 \mathrm{ml} 90 \%$ acetone followed by extraction in a $4{ }^{\circ} \mathrm{C}$ shaking incubator for at least $2 \mathrm{~h}$. After centrifugation $(1000 \mathrm{~g}$; $5 \mathrm{~min})$, the chlorophyll concentration in the supernatant was measured with a fluorometer (Turner 10-AU-005).

Primary production was measured by the ${ }^{14} \mathrm{C}$ assimilation method (Parsons et al., 1984). Acidcleaned polycarbonate bottles $(250 \mathrm{ml}$, Nalgene) were filled with seawater prescreened through $200 \mu \mathrm{m}$ mesh, and then inoculated with $10 \mu \mathrm{Ci}$ $\mathrm{NaH}^{14} \mathrm{CO}_{3}$. Samples were collected at dawn and incubated for $6 \mathrm{~h}$ with artificial lighting, and incubators were cooled with running surface seawater. Following incubation, the samples were filtered through $\mathrm{GF} / \mathrm{F}$ filters (Whatman, $25 \mathrm{~mm}$ ) under low vacuum $(<100 \mathrm{mmHg})$. The filters then were placed in scintillation vials and stored in the dark. Upon returning to the laboratory, $0.5 \mathrm{ml}$ of $2 \mathrm{~N} \mathrm{HCl}$ was added and the vials were left open overnight in a hood at room temperature. Next, $10 \mathrm{ml}$ of scintillation cocktail (Ultima Gold LLT) was added, and total activity on filters was counted in a liquid scintillation counter (Packard 2700TR). The $P^{\mathrm{B}}-E$ curve was constructed from the incubation results. Primary production at each depth was calculated from the measured photosynthetically active radiation at the sea surface, total downwelling attenuation, in situ $\mathrm{Chl} a$ concentration, and the photosynthetic parameters from incubation (Jassby and Platt, 1976; Gong et al., 1999). Details of the primary production measurements will be reported elsewhere.

An Acoustic Doppler Current Profiler mooring was deployed at Site SCS1 $\left(18.0^{\circ} \mathrm{N}, 115.6^{\circ} \mathrm{E}\right)$ near Site S1 from April 1998 to April 1999 with one service in between. The $153 \mathrm{kHz}$ broad-band ADCP was mounted at $300 \mathrm{~m}$ below surface looking upward. The bin length of the ADCP was set at $8 \mathrm{~m}$. The local sound speed was estimated from CTD hydrocasts at the deployment and retrieval of the mooring. Details will be reported elsewhere.

\section{Results and discussion}

In this section, we first present observational data to illustrate the SCS biogeochemical features. Then we present model results from $4^{\circ} \mathrm{N}$ to $23.6^{\circ} \mathrm{N}$ and west of the Luzon Strait $\left(121.4^{\circ} \mathrm{E}\right)$. The chosen domain of interest excludes buffer zones adjacent to open ocean boundaries. To illustrate the model's convergence in time after initialization, Fig. 3 shows the monthly mean concentrations of DIN, phytoplankton, zooplankton and detritus and the chlorophyll/phytoplankton ratio for the first 3 years of model simulation. The mean values are derived by performing a volume average over the entire SCS area and over the top $135 \mathrm{~m}$ of the water column. It took less than 10 months for the biogeochemical components to reach a regular annual cycle. The modeled mean nitrate concentration (Fig. 3a) in the upper water column $(0$ $135 \mathrm{~m}$ ) shows a nearly sinusoidal fluctuation with recurring peaks in winter corresponding to the stronger northeast monsoon. On an inter-annual time scale, the mean nitrate concentration increases slowly with time. The other biogeochemical components also show similar but less pronounced inter-annual drift. In the first 6 months of model simulation, the phytoplankton concentration decreases considerably from the initial concentration to the observed level (see temporal variation of chlorophyll). This makes sense, because the fixed profile shape assumed for phytoplankton overestimates the initial 

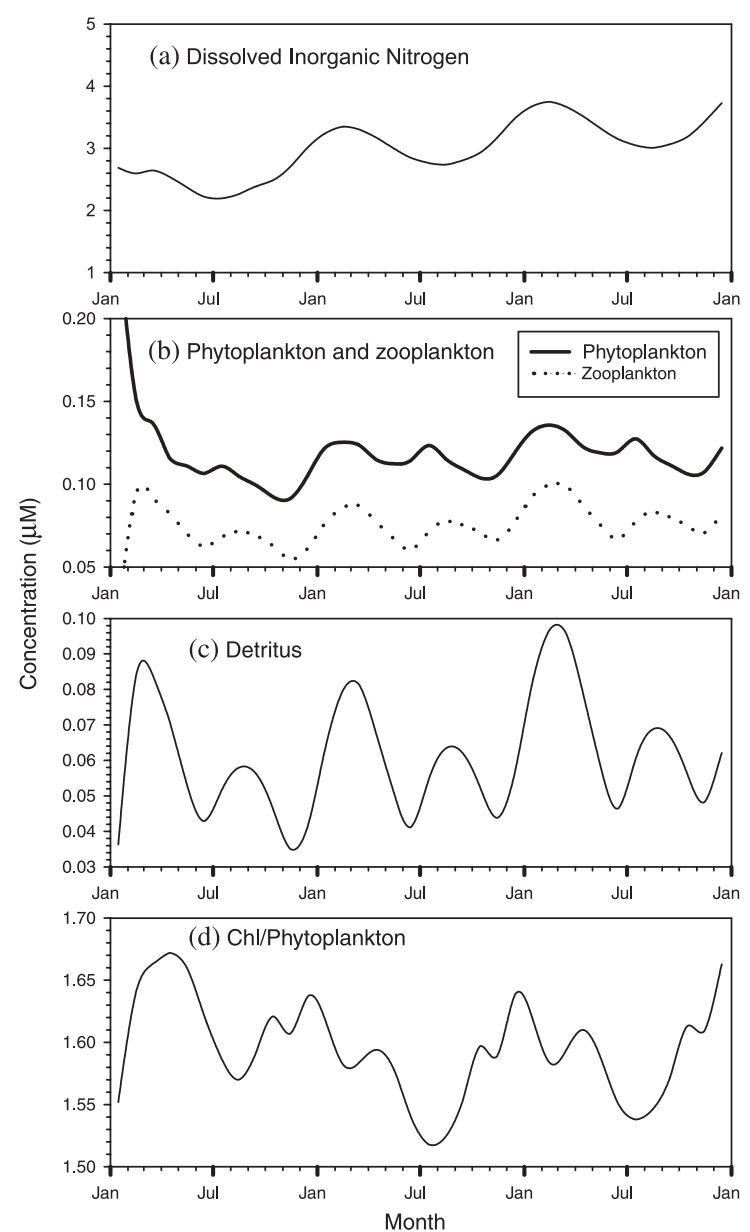

Fig. 3. Volume-averaged monthly values of biogeochemical variables in the upper $135 \mathrm{~m}$ for the first 3 years of the model run.

phytoplankton standing stock because of the high CZCS pigment values in the coastal zone. The model, though oversimplified, is capable of capturing the main biogeochemical features of the SCS to be illustrated later.

The modeled biogeochemical quantities contain a minor inter-annual drift superimposed on a highly repetitive yearly cycle. The inter-annual drift, though minor, warrants a discussion. The circulation component of this model approaches a steady annual cycle rather fast, because the incoming and outgoing transports through open ocean boundaries are exactly balanced. This is achieved through specification of depth-integrated transports entering and leaving open boundaries. Although the depth-integrated transports are specified, vertical variations of inflow and outflow nevertheless vary in time because they are determined by radiation conditions. In fact, vertical variations of incoming and outgoing currents are often large enough to produce reverse flow at depth. Since the vertical profiles of inflow and outflow vary greatly in time, the balance between incoming and outgoing fluxes of biogeochemical components through open boundaries cannot be taken for granted. A slight imbalance could accumulate in time and produce an inter-annual drift. This problem, in our view, is generic in all regional ocean models with excessive open ocean boundaries. Fortunately, the inter-annual drift of biogeochemical components is small in this model. In terms of spatial distributions, the biogeochemical variables contain highly repeatable seasonal patterns; changes from one year to the next are hardly visible. We have chosen the third year's results to illustrate essential features of the model, because the model-data discrepancy is generally minimal in the third year. One could choose another year to derive similar conclusions.

In the following, we first present observed depth profiles of nitrate and chlorophyll to illustrate the contrast between SCS and the western Philippine Sea. The modeled nitrate profile is also included for comparison. Next we show surface pigment/ chlorophyll distributions derived from CZCS and SeaWiFS data to demonstrate the seasonality in the SCS, and display modeled chlorophyll distributions to argue for the processes responsible for the observed features. Then we briefly discuss upwelling processes in three regions of the SCS and the relationship between upwelling and chlorophyll in the annual cycle. Finally, we assess primary production and new production based on observational data and modeling.

\subsection{Vertical profiles of chlorophyll and DIN}

Fig. 4 illustrates the essential difference of chlorophyll profiles between the SCS and the western Philippine Sea. Both seas are characterized by low surface concentration of chlorophyll and a 


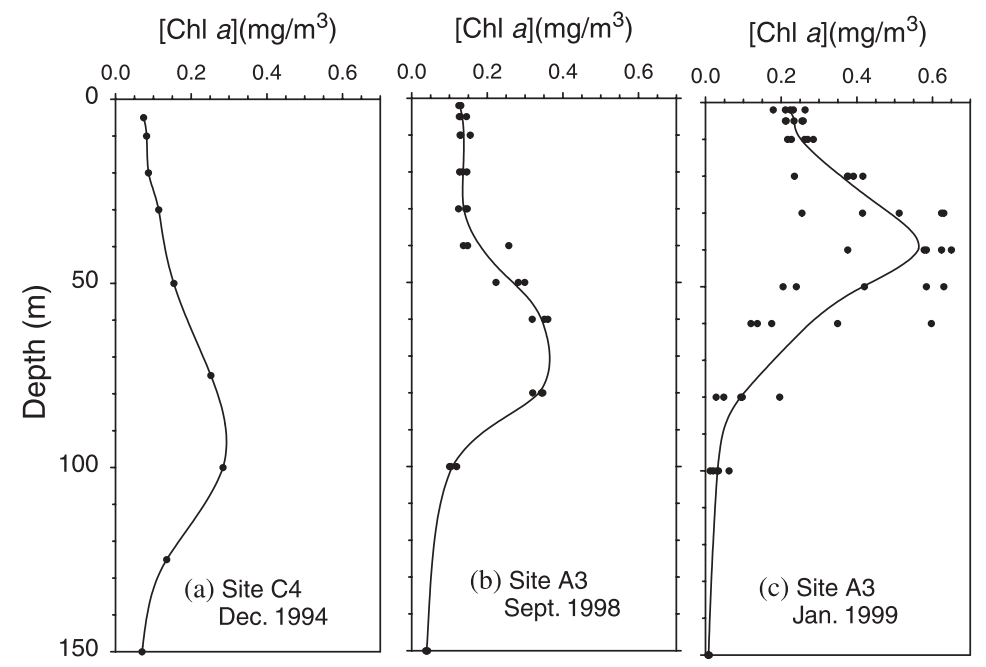

Fig. 4. Chlorophyll profiles observed in the western Philippine Sea and the SCS: (a) one profile obtained in December 1994 at Site C4, which is near the open boundary B shown in Fig. 1; (b) three profiles obtained in September 1998 at Site A3, which is about $2.5^{\circ}$ east of Site S1; and (c) five profiles obtained in January 1999 at Site A3.

prominent SCM as shown in the three examples in Fig. 4. Despite the generally low surface concentrations, the observations indicate that the mean chlorophyll concentration inside the SCS is about twice that in the western Philippine Sea. The profile in the western Philippine Sea (Fig. 4a) was obtained at Site $\mathrm{C} 4\left(18.31^{\circ} \mathrm{N}, 124.61^{\circ} \mathrm{E}\right)$ east of Luzon in December 1994 by Yang (1995). It has the lowest surface concentration $\left(0.074 \mathrm{mg} / \mathrm{m}^{3}\right)$ and very deep SCM $(100 \mathrm{~m})$. Data obtained at Site A3 $\left(18.0^{\circ} \mathrm{N}, 118.5^{\circ} \mathrm{E}\right)$, which was at about the same latitude as Site C4 but west of Luzon, are shown for September 1998 (Fig. 4b) and January 1999 (Fig. 4c). In September 1998, the surface value at Site A3 $\left(0.13 \mathrm{mg} / \mathrm{m}^{3}\right)$ is about twice that at Site C4, and the SCM was at about $75 \mathrm{~m}$. Observations at the same site in January 1999 showed even higher surface concentrations (0.18$\left.0.26 \mathrm{mg} / \mathrm{m}^{3}\right)$ and shallower SCM $(40-50 \mathrm{~m})$. This lends support to the suggested phytoplankton bloom in the SCS off Luzon in winter based on CZCS data (Tang et al., 1999).

Fig. 5 contrasts DIN profiles inside and outside the SCS. The DIN data inside the SCS represent the average of nine profiles obtained in the area between $18.5^{\circ} \mathrm{N}$ and $19.1^{\circ} \mathrm{N}$ and $116.2^{\circ} \mathrm{E}$ and $117.7^{\circ} \mathrm{E}$ on OR-I Cruise 311 in March 1993. The profile outside the SCS was derived from the observed temperature profile at the aforementioned Site C4 (Yang, 1995) and the temperaturenitrate relationship observed in the western Philippine Sea (Gong et al., 1992). This profile outside the SCS, indicated by the dashed curve in Fig. 5, provides information on the inflow of the Kuroshio at the open boundary B (Fig. 1). In the upper ocean, the DIN concentration inside the SCS is considerably higher than that in the western Philippine Sea. In waters deeper than $600 \mathrm{~m}$, however, the DIN concentrations of the western Philippine Sea approach or even exceed those at the same depths in the SCS (Gong et al., 1992).

The model-predicted DIN profile for March is illustrated by the solid curve in Fig. 5. This profile is derived by averaging the model output in the same area in the SCS. The modeled profile fits the observed mean values quite well, indicating that the model has succeeded in maintaining the uplifted nitracline by pumping enough nutrients upward. In more detail, the modeled nitracline is a bit shallower than the observed one, but the discrepancy is not serious. 


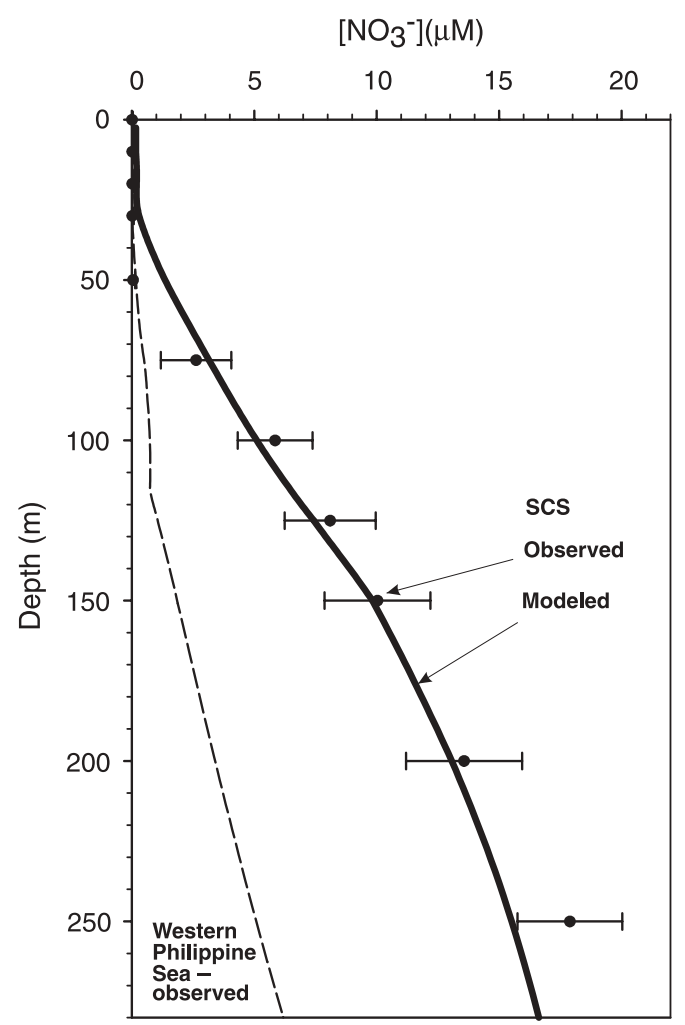

Fig. 5. DIN profiles in the western Philippine Sea and the SCS. The dashed curve is the $\left[\mathrm{NO}_{3}^{-}+\mathrm{NO}_{2}^{-}\right]$profile at Site $\mathrm{C} 4$ near the open boundary $\mathrm{B}$ (see text). Dots represent the average $\left[\mathrm{NO}_{3}^{-}+\mathrm{NO}_{2}^{-}\right]$distribution of nine stations from $18.5^{\circ} \mathrm{N}$ to $19.1^{\circ} \mathrm{N}, 116.2^{\circ} \mathrm{E}$ to $117.7^{\circ} \mathrm{E}$ obtained in March 1992 . The solid curve is the modeled DIN profile for March.

\subsection{Surface distributions of chlorophyll}

Ocean color images of the SCS reveal the seasonal changes of the chlorophyll distribution pattern in the SCS. Four cases are presented in the following to represent the peak conditions of the summer and winter monsoons and the two intermonsoon periods. Images of pigment concentration derived from composite monthly CZCS data are used for April, October and December. For August, the monthly composite image of SeaWiFS chlorophyll of August 2000 is used.

In April, before the onset of the southwest monsoon, the CZCS image (Fig. 6a) shows very low chlorophyll concentration almost everywhere in the SCS except in the coastal zone. In the central basin, the CZCS-derived concentration is mostly below $0.1 \mathrm{mg} \mathrm{m}^{-3}$, especially in the inner portion of the central basin $\left(<0.05 \mathrm{mg} \mathrm{m}^{-3}\right)$. In most coastal areas, the relatively high chlorophyll concentrations may be attributed to DIN provided by river runoff. Under the summer monsoon in August, the SeaWiFS image (Fig. 7a) shows a band of high chlorophyll concentration about $100 \mathrm{~km}$ wide extending $600 \mathrm{~km}$ northeastward from the Mekong River mouth. Elevated chlorophyll concentrations also appear along the coast of southwestern China and extend into the southwestern reaches of the Taiwan Strait (Fig. 7a).

During the inter-monsoon period in October, the chlorophyll concentrations again dropped to very low levels (Fig. 8a), similar to the condition during the spring inter-monsoon period (Fig. 6a). The pigment concentrations in the eastern half of the basin, mostly below $0.1 \mathrm{mg} \mathrm{m}^{-3}$, are notably lower than those in the western half. When the winter monsoon peaks in December, the CZCS image (Fig. 9a) shows patches of elevated chlorophyll concentrations off northwest Luzon. Tang et al. (1999) reported similar findings in winter. In the southern SCS, the CZCS image of December (Fig. 9a) shows a very strong signal in the coastal zone off southern Vietnam (up to $2-3 \mathrm{mg} \mathrm{m}^{-3}$ ), off the Malay Peninsula and north of Borneo (up to $5 \mathrm{mg} \mathrm{m}^{-3}$ ). The strong ocean color patch off the southern tip of Vietnam appears to extend from the Mekong Delta and penetrate into the Gulf of Thailand.

An important challenge to the model skill is to simulate the chlorophyll distribution patterns in different seasons. The monthly results corresponding to the four cases are represented by the model output for the 15th of each month. In April, the model results (Fig. 6b) also show very low chlorophyll concentrations except in the coastal zone. While this is in qualitative agreement with observations, the modeled values in the SCS proper are mainly between 0.1 and $0.2 \mathrm{mg} \mathrm{m}^{-3}$, which are consistently higher than the CZCSderived concentrations. It is shown later that observed chlorophyll concentrations at Site S1 in the central northern SCS rarely dropped below $0.1 \mathrm{mg} \mathrm{m}^{-3}$, suggesting that the very low CZCS 


\section{CZCS (April)}

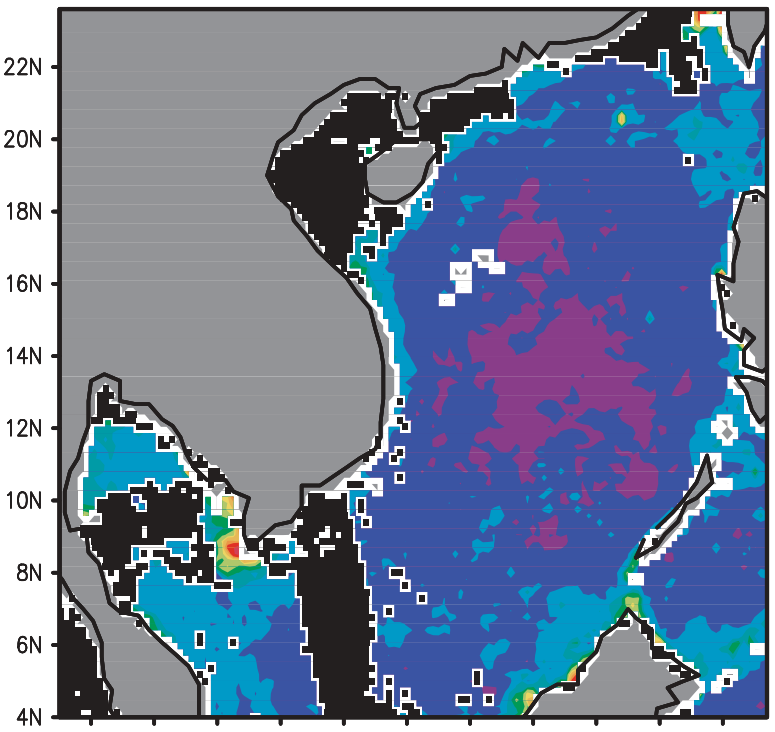

(a) 100E $102 \mathrm{E}$ 104E $106 \mathrm{E}$ 108E $110 \mathrm{E}$ 112E $114 \mathrm{E}$ 116E $118 \mathrm{E}$ 120E
Modelled surface Chl (April)

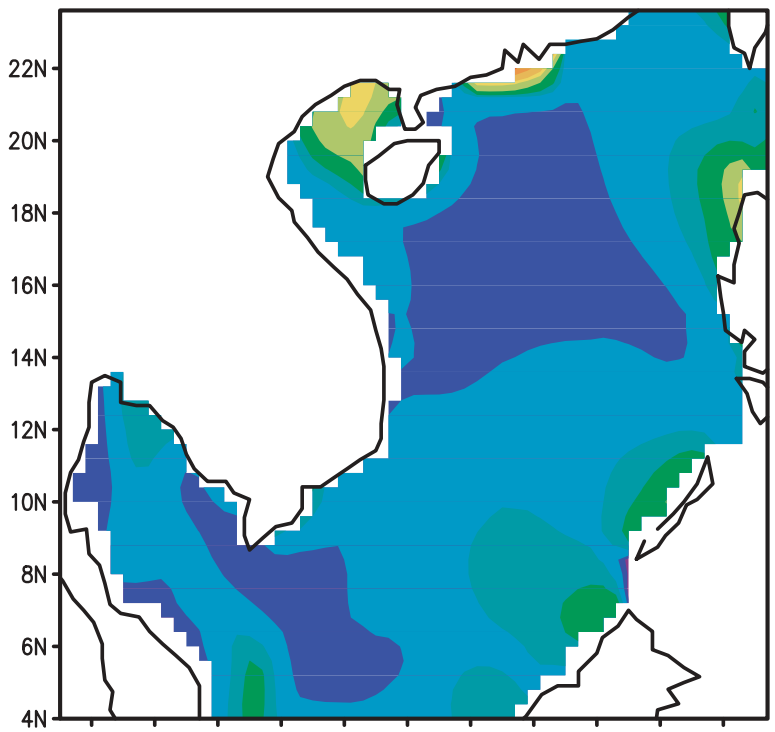

(b) 100E 102E $104 \mathrm{E}$ 106E $108 \mathrm{E}$ 110E $112 \mathrm{E}$ 114E $116 \mathrm{E}$ 118E $120 \mathrm{E}$
0.05
0.1
$\begin{array}{lll}0.2 & 0.3 & 0.5\end{array}$
0.8
1.5
5

Fig. 6. Sea-surface chlorophyll $\left(\mathrm{mg} \mathrm{m}^{-3}\right)$ distribution for April: (a) CZCS data and (b) model output for Layer 1 (2.5 m).

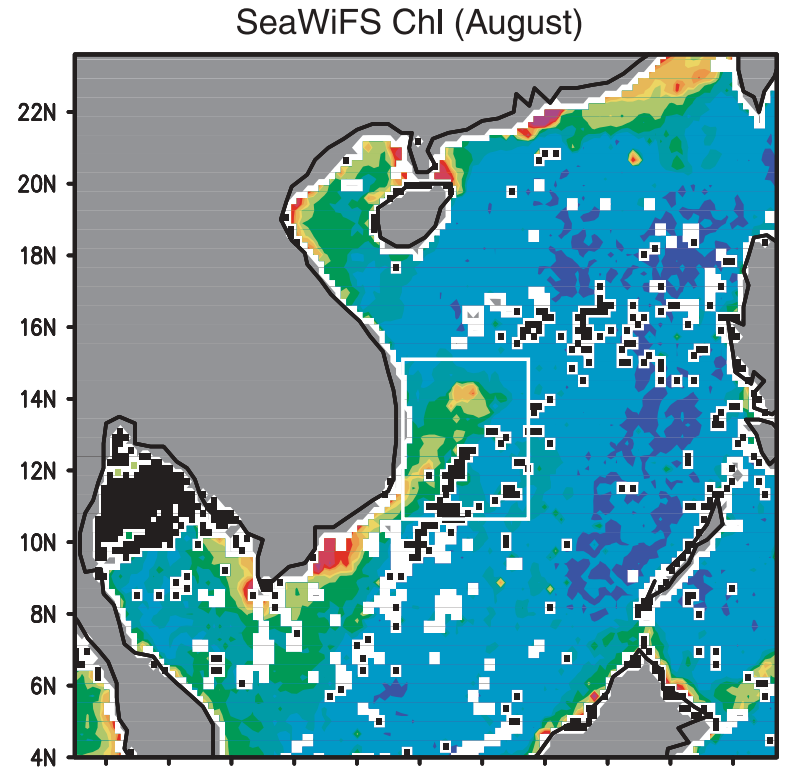

(a) 100E 102E 104E 106E 108E 110E 112E 114E 116E 118E 120E

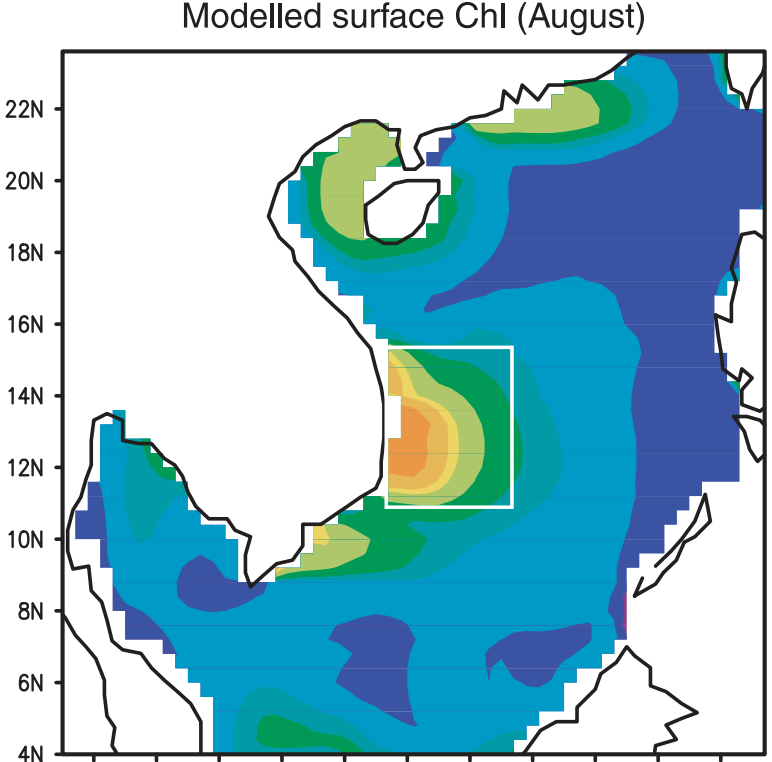

(b) $100 \mathrm{E}$ 102E $104 \mathrm{E}$ 106E $108 \mathrm{E}$ 110E 112E $114 \mathrm{E}$ 116E $118 \mathrm{E}$ 120E

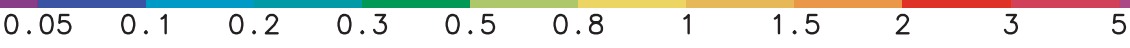

Fig. 7. Same as Fig. 6 except for August. CZCS data have been replaced by the monthly composite SeaWiFS chlorophyll data for August 2000, because serious cloud coverage masked a major portion of the CZCS data. Rectangles off Vietnam is an upwelling area (V) discussed in the text. 

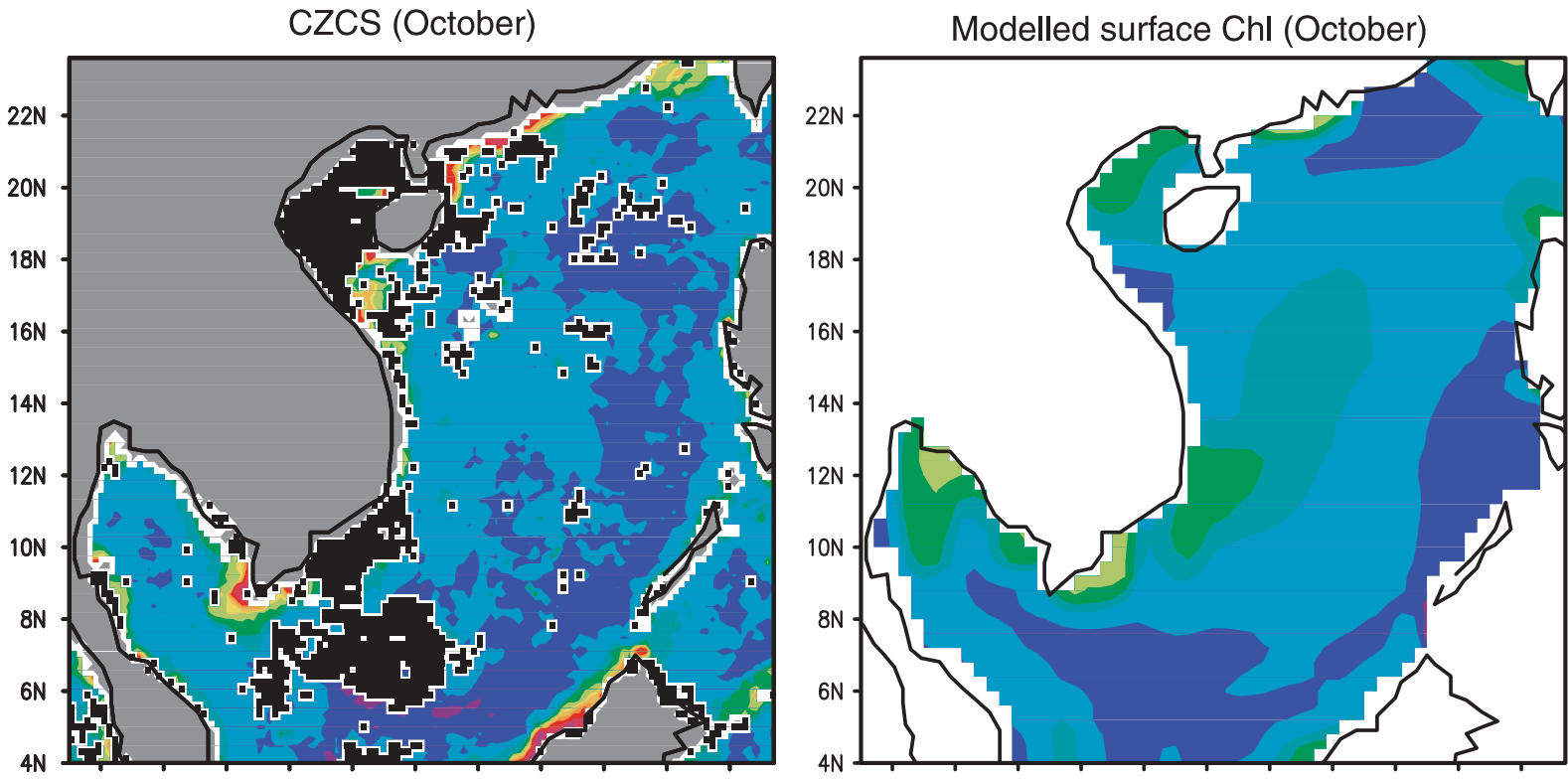

(a) 100E 102E 104E 106E 108E 110E 112E 114E 116E 118E 120E

(b) 100E 102E 104E 106E 108E 110E 112E 114E 116E 118E 120E

$$
\begin{array}{lllllllllll}
0.05 & 0.1 & 0.2 & 0.3 & 0.5 & 0.8 & 1 & 1.5 & 2 & 3 & 5
\end{array}
$$

Fig. 8. Same as Fig. 6 except for October.

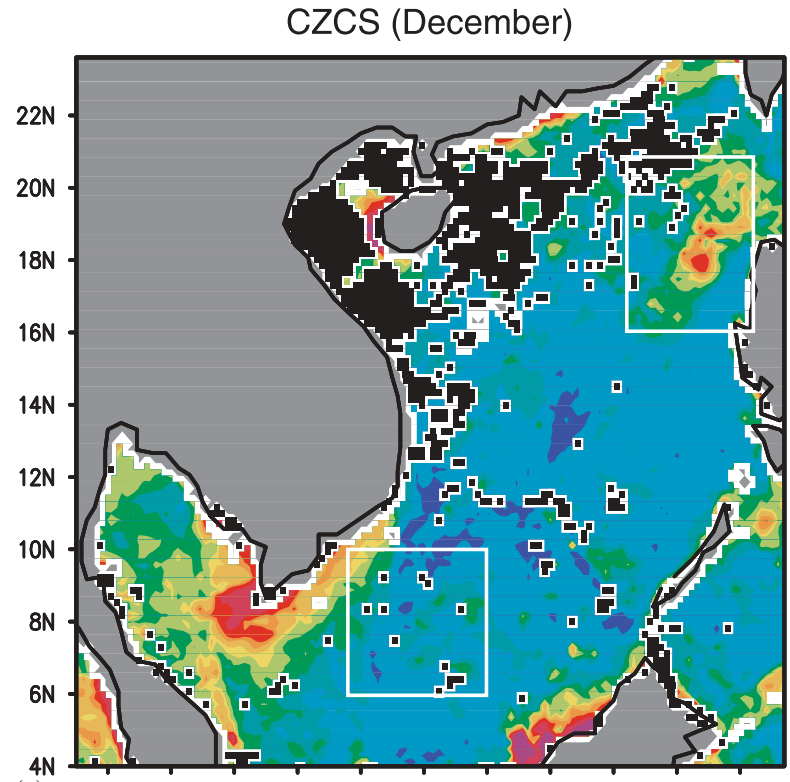

(a) 100E 102E 104E 106E 108E 110E 112E 114E 116E 118E 120E

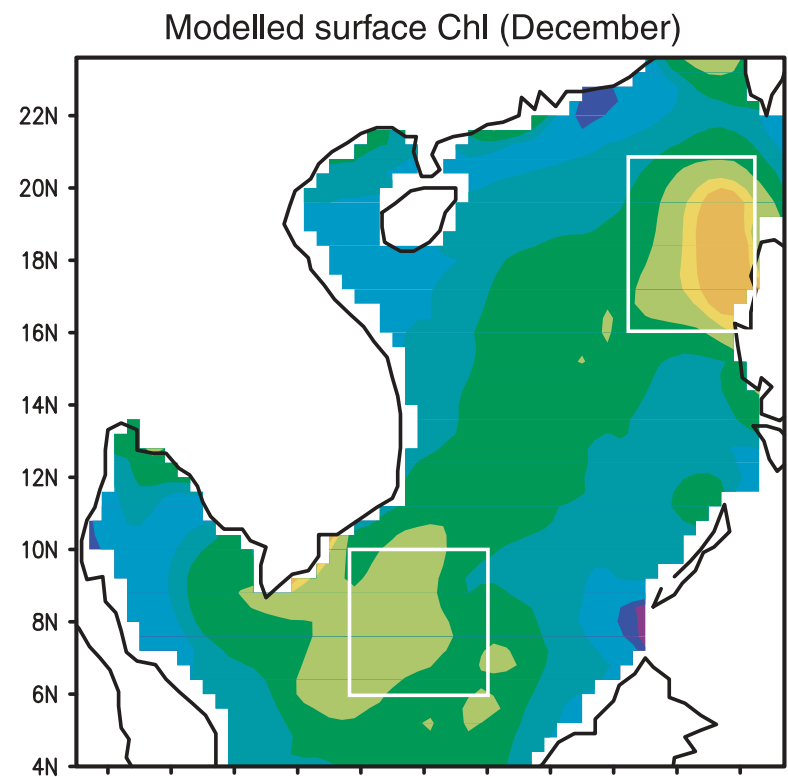

(b) 100E 102E 104E 106E 108E $110 \mathrm{E}$ 112E $114 \mathrm{E}$ 116E $118 \mathrm{E}$ 120E

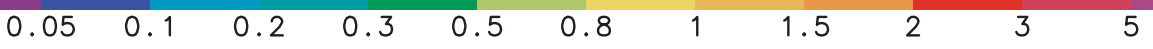

Fig. 9. Same as Fig. 6 except for December. Rectangles off northwest Luzon and southeast of Vietnam are upwelling areas (L and S) discussed in the text. 
values are underestimated as suggested by Gregg and Conkright (2001). In spite of minimal riverine inputs from the Philippines, both the CZCS image and the model results show a notable patch of slightly elevated chlorophyll concentration off northwestern Luzon, which is probably the remnant of winter upwelling (Udarbe-Walker and Villanoy, 2001).

At the height of summer monsoon (August), the model produces high chlorophyll patches off the Pearl River Mouth, in the Gulf of Tonkin, off the east coast of Vietnam and off the Mekong River Mouth (Fig. 7b). Elsewhere, chlorophyll concentrations are mostly below $0.2 \mathrm{mg} \mathrm{m}^{-3}$. The riverine discharges are responsible for some of the coastal high values, but the high chlorophyll patch off the Vietnamese coast north of the Mekong River mouth shown in both the SeaWiFS image and the model results is apparently induced by the upwelling under southwest monsoon (Chao et al., 1996a). However, the model overestimates the area of the patch but underestimates the maximum intensity. The model also fails to generate the elevated chlorophyll concentrations in the southern reaches of the Taiwan Strait. Besides high values, both the model and the satellite image show rather low chlorophyll concentrations $\left(<0.1 \mathrm{mg} \mathrm{m}^{-3}\right)$ in the eastern half of the basin, probably due to wind-induced downwelling along the eastern wall of the basin (Shaw and Chao, 1994; Udarbe-Walker and Villanoy, 2001).

The modeled surface chlorophyll concentrations in October in the SCS proper (Fig. 8b) are mostly below $0.2 \mathrm{mg} \mathrm{m}^{-3}$ with an east-west gradient. The distribution of low values along the eastern and southern boundaries of the SCS resembles the CZCS image (Fig. 8a). This is apparently the leftover of downwelling in summer. In December, the model predicts high chlorophyll concentrations (up to $1.4 \mathrm{mg} \mathrm{m}^{-3}$ ) off northwest Luzon and moderately elevated chlorophyll concentrations (up to $0.7 \mathrm{mg} \mathrm{m}^{-3}$ ) north of the Sunda Shelf (Fig. 9b). Both areas are regions of upwelling according to model-predicted circulation (Chao et al., 1996a; Shaw et al., 1996). The CZCS image (Fig. 9a) does show significant chlorophyll concentrations off northwest Luzon, but only scattered patches of slightly elevated chlorophyll level (around $0.5 \mathrm{mg} \mathrm{m}^{-3}$ ) north of the Sunda Shelf. On the other hand, shipboard observations (Huang and Chen, 1997) show relatively large patches of elevated chlorophyll levels (up to $0.7 \mathrm{mg} \mathrm{m}^{-3}$ ) between Vietnam and Borneo, but their positions are farther away from the Vietnamese coast. Details will be discussed later. In the Mekong outflow region, the modeled chlorophyll distribution shows downstream expansion of a patch with moderately elevated chlorophyll $\left(0.3-0.8 \mathrm{mg} \mathrm{m}^{-3}\right)$ from the river delta into the Gulf of Thailand, but both the concentration and downstream expansion are much reduced relative to the CZCS image. Off the coast of Borneo or the Malay Peninsula, the model does not produce intense chlorophyll patches.

The relatively low modeled chlorophyll levels in the coastal areas in the southern SCS and southern reaches of the Taiwan Strait deserve comment. Since the parameter values for phytoplankton growth were adopted from values derived in the study of the Sargasso Sea (Doney et al., 1996), which is oligotrophic, they may not be suitable for the coastal environment, where nutrient levels are much higher than in the oligotrophic waters in the basin interior. On the other hand, very high CZCS pigment concentrations in the coastal zone may not be real. The highest chlorophyll concentration observed in December in the coastal zone off Borneo was only $1.5 \mathrm{mg} \mathrm{m}^{-3}$ (Huang and Chen, 1997), which is considerably lower than the CZCS values of $3-5 \mathrm{mg} \mathrm{m}^{-3}$. In determining pigment/ chlorophyll concentrations from CZCS/SeaWiFS data, the algorithms are applicable to Case I waters. However, Case II waters are often encountered in the coastal zone, where the algorithm may produce unreliable chlorophyll or pigment concentrations due to interferences from suspended sediments or colored dissolved organic matter (CDOM) (Carder et al., 1986; IOCCG, 2000). Such cases have been demonstrated for the western Pacific marginal seas by SeaWiFS and OCTS data (Gong et al., 1998; IOCCG, 2000). December is at the peak of the rainy season (Wyrtki, 1961) in the southern SCS; the heavy rain ( $300 \mathrm{~mm} / \mathrm{month})$ may have washed out suspended sediments or CDOM from land that may contribute to the intense color in the coastal zones. 
The long stretch of intense color in the Gulf of Thailand may have been caused partially by the CDOM, which is quite long-lived and traceable over a long distance from its origin (Blough et al., 1993). Moreover, the northeast monsoon, which is strongest in December, may have induced sediment resuspension that also may contribute to the strong coastal ocean color. A similar situation may occur in the northern SCS in summer, where the Pearl River provides the runoff from land and the southwest monsoon drives the river plume northward.

\subsection{Upwelling and temporal variation of chlorophyll}

After showing the seasonal changes of chlorophyll distribution pattern, we examine the temporal variation of chlorophyll content and the upwelling DIN fluxes quantitatively. To facilitate discussion below, three upwelling regions are depicted in Fig. 10, with letters L, V and S representing northwest of Luzon, east of Vietnam and north of Sunda Shelf. Subscript $u$ defines a subarea of intense upwelling or the upwelling center within each upwelling region.

The three upwelling centers $\left(\mathrm{L}_{\mathrm{U}}, \mathrm{V}_{\mathrm{U}}\right.$ and $\mathrm{S}_{\mathrm{U}}$ in Fig. 10) are delineated from the distribution of modeled vertical fluxes of DIN at depth of $125 \mathrm{~m}$, which is at the base of the euphotic zone. Fig. 11 shows the DIN flux and flow field at $125 \mathrm{~m}$ depth. August and December results are shown to illustrate peak upwelling conditions under summer and winter monsoons, respectively. The upwelling centers are quite small; subsequent dispersal to upper depths spreads DIN to larger areas. The monthly mean DIN fluxes in the upwelling centers are calculated and plotted along with the mean wind stress in Fig. 12. Fig. 13 shows the temporal variation of monthly mean surface concentrations of chlorophyll from shipboard observations, ocean color data and the model in the three upwelling regions. For inter-comparison, we also make similar comparison among in situ data, CZCS data and model-derived results at Site $\mathrm{S} 1$, which is outside the three upwelling regions. The comparison at Site $\mathrm{S} 1$ is included in the bottom panel of Fig. 13.

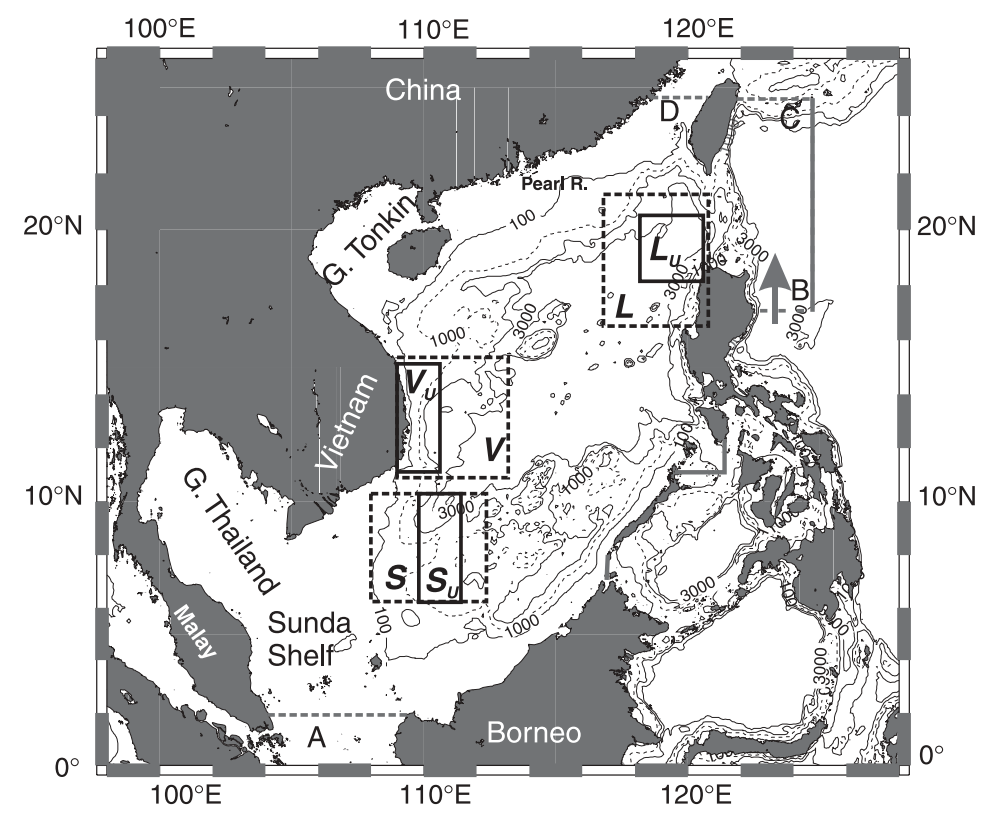

Fig. 10. Three regions of high sea-surface chlorophyll concentrations: L, V and S. Subareas representing upwelling centers inside the three regions are $\mathrm{L}_{\mathrm{U}}, \mathrm{V}_{\mathrm{U}}$ and $\mathrm{S}_{\mathrm{U}}$. 
DIN flux (mmolN m $\left.{ }^{-2} \mathrm{~d}^{-1}\right)$ and flow field at $125 \mathrm{~m}$
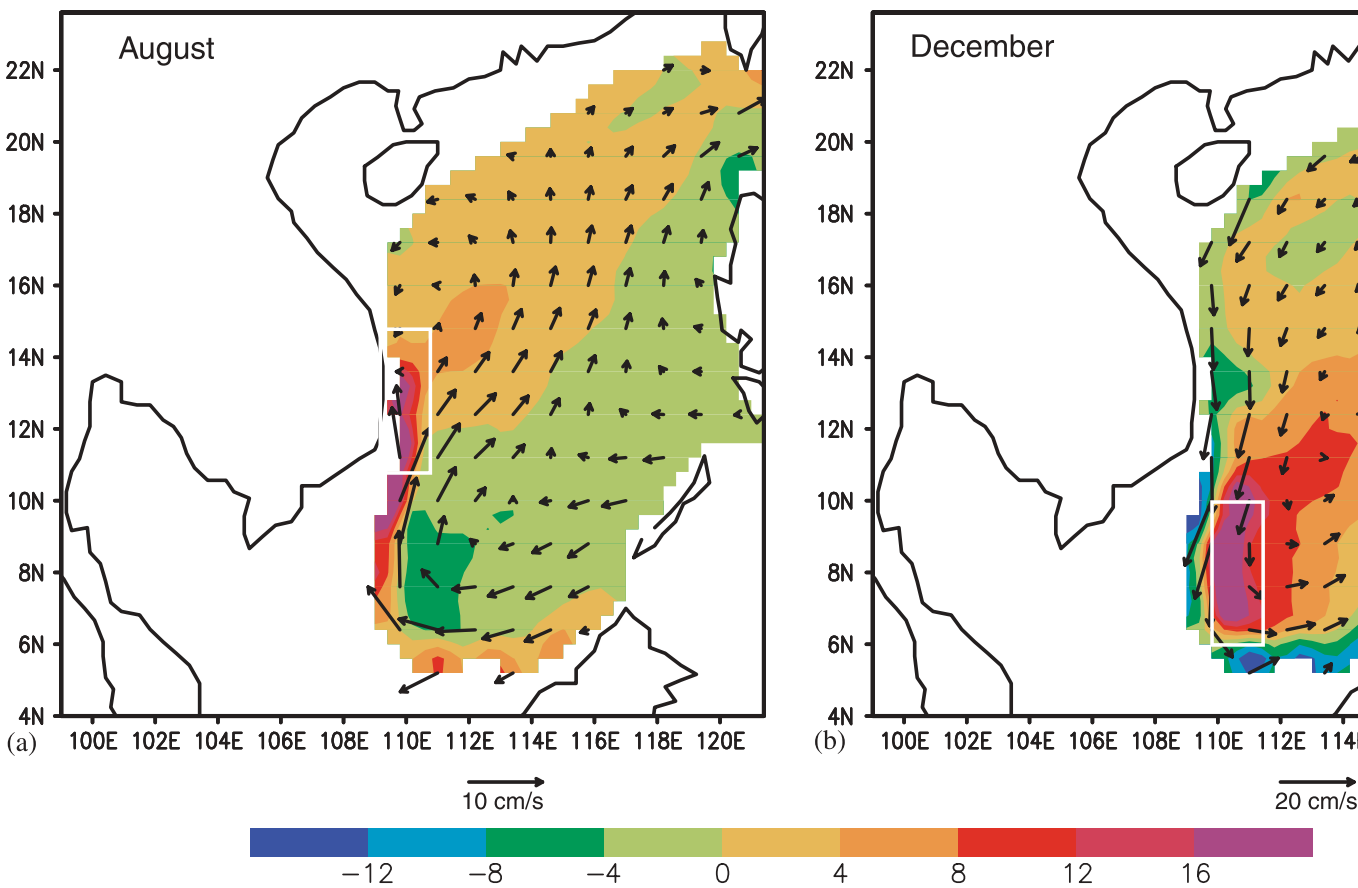

Fig. 11. Model-generated vertical flux of DIN in units of $\mathrm{mmol} \mathrm{N} \mathrm{m} \mathrm{N}^{-2}$ and flow field at $125 \mathrm{~m}$ in August (a) and December (b). Rectangles indicate areas used to calculate mean DIN fluxes shown in Fig. 12.

\subsubsection{Region L: northwest of Luzon}

Upwelling off NW Luzon is confined to a small area as delineated in Fig. 11b. The upwelling is attributed to subsurface convergence of the northward jet off the west coast of Luzon (Shaw et al., 1996). Further, local wind stress curl is positive in winter, inducing Ekman suction or upwelling (Chao et al., 1996b). The modeled upwelling starts in October (Fig. 12b), which agrees with the onset of isotherm uplifting off northwest Luzon (Udarbe-Walker and Villanoy, 2001).

The CZCS-SeaWiFS data (Fig. 13a) reveal a strong peak $\left(0.5 \mathrm{mg} \mathrm{m}^{-3}\right)$ in December, a weak peak $\left(0.16 \mathrm{mg} \mathrm{m}^{-3}\right)$ in July and very low values during inter-monsoon periods. The shipboard observations at Sites A1 $\left(19.0^{\circ} \mathrm{N}, 118.0^{\circ} \mathrm{E}\right)$ and A3 confirm the winter bloom of phytoplankton and the low chlorophyll during inter-monsoon. The modeled mean surface chlorophyll concentration (Fig. 13a) stays very low $\left(<0.1 \mathrm{mg} \mathrm{m}^{-3}\right)$ from

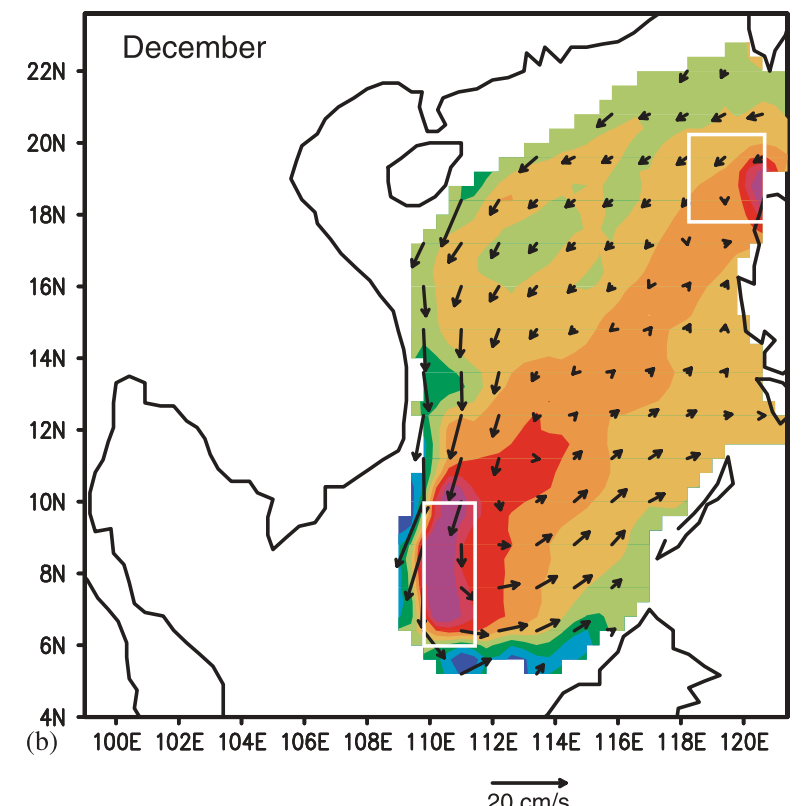

(b) 100E 102E 104E 106E 108E 110E 112E 114E $116 \mathrm{E}$ 118E $120 \mathrm{E}$

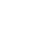



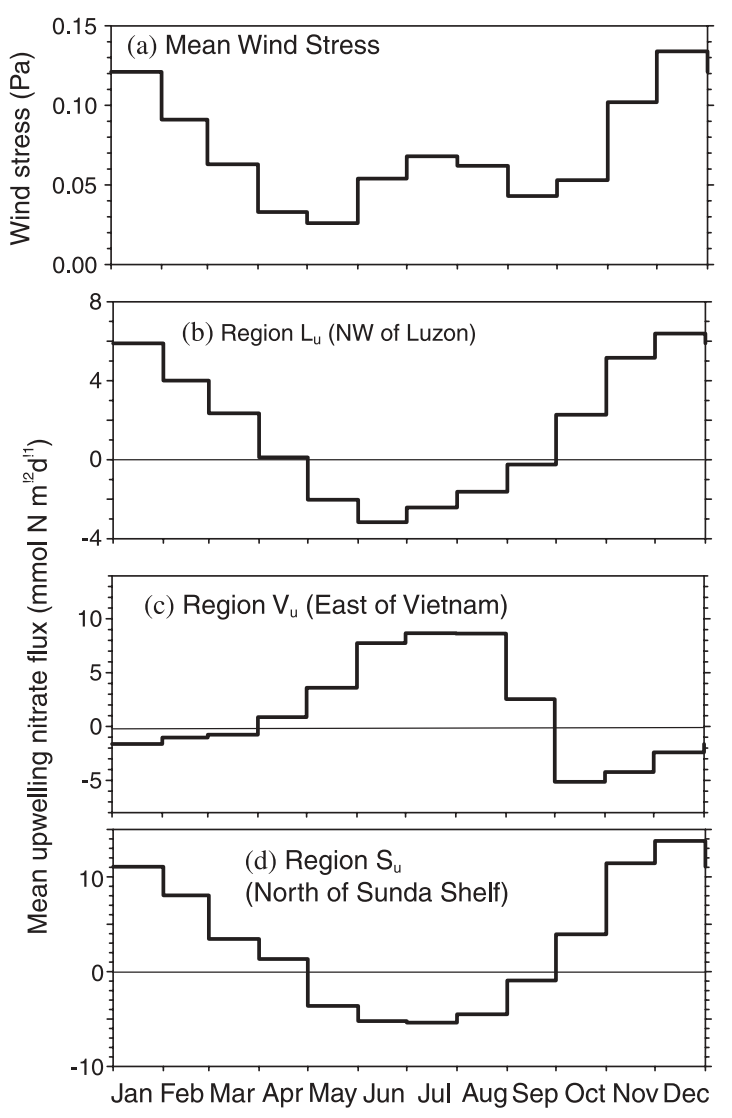

Fig. 12. Wind stress (a) and mean vertical DIN fluxes in three upwelling centers $((b)-(d))$.

distribution similar to that for December (Fig. 9b), only slightly more expanded in area. In contrast, the CZCS imagery (Fig. 14b) indicates much more dispersed chlorophyll patches spreading across the entire northern SCS. The patches have rather low chlorophyll concentrations $\left(0.2-0.4 \mathrm{mg} \mathrm{m}^{-3}\right)$ but are clearly above the background level of $0.1 \mathrm{mg} \mathrm{m}^{-3}$. Interestingly, the spreading of the chlorophyll patches appears to follow the modeled mean surface current to the north of $18^{\circ} \mathrm{N}$ (Fig. 14b).

The lack of downstream dispersal of chlorophyll in the model (Fig. 14a) suggests that the actual flow field is stronger than the modeled surface current. Measurements from a moored ADCP near Site S1 indicate that the real current is indeed stronger. The vector representing the mean velo-
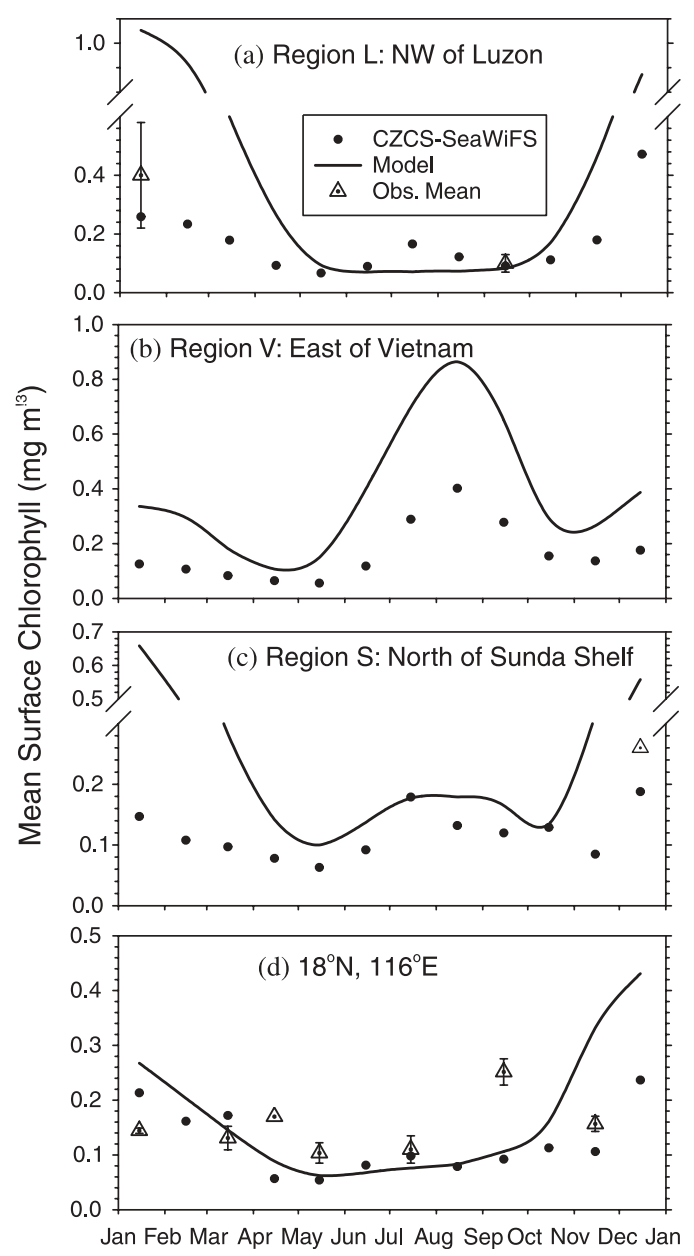

Fig. 13. Comparison of monthly mean chlorophyll concentration from model prediction (curves), CZCS-SeaWiFS data (dots) and shipboard measurements (triangles with error bars indicating data variance): (a) Region L off NW Luzon; (b) Region V east of Vietnam; (c) Region S north of Sunda Shelf; and (d) Site S1.

city at $30 \mathrm{~m}$ below surface (the top layer from the ADCP measurement) averaged over the period from 15 December 1998 to 14 January 1999 is included in Fig. 14 as a bold arrow. The actual flow at $30 \mathrm{~m}$ depth $(26 \mathrm{~cm} / \mathrm{s})$ is about twice the depth-averaged surface flow in the model. In terms of direction, the actual flow is more westward than the northwestward flow in the model. The veering is expected under the winter northeast monsoon. Depth-averaged surface flow contains more Ekman veering (to the northwest) than flow below. 


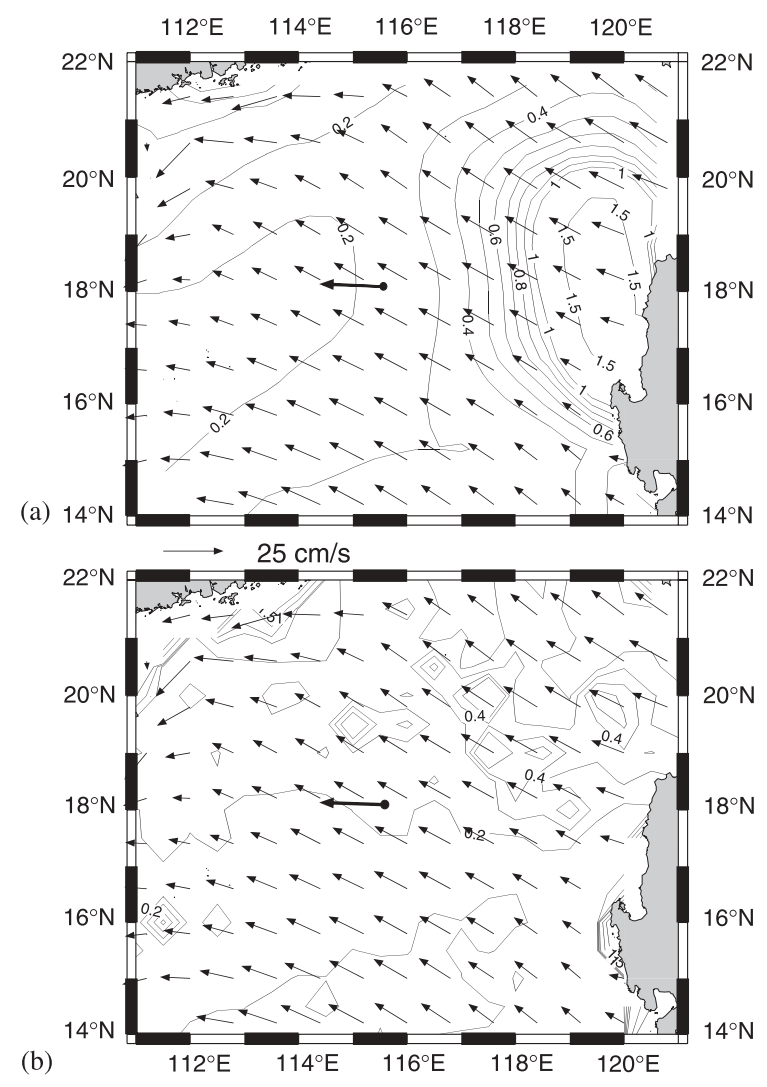

Fig. 14. Model-data comparison of surface chlorophyll $\left(\mathrm{mg} \mathrm{m}^{-3}\right)$ distribution in the northern SCS in January: (a) model result and (b) CZCS data. Superimposed is the modelgenerated mean flow field averaged over the top $30 \mathrm{~m}$ and from mid-December to mid-January. The bold arrow indicates the observed mean velocity at $30 \mathrm{~m}$ depth at Site S1 from 15 December 1998 to 14 January 1999.

The measured velocity contains high variability as indicated by the rather large variances for the zonal $(-26 \pm 10 \mathrm{~cm} / \mathrm{s})$ and meridional $(0.9 \pm 14 \mathrm{~cm} /$ s) components. This high variability, normally indicative of eddy activities, is conspicuously missing in the model. The use of coarse grid spacing $\left(0.4^{\circ}\right)$ necessitates the use of high horizontal viscosity, which in turn results in weaker flow and suppresses mesoscale eddies.

Besides insufficient advection, the model's oversimplified biological scheme may also contribute to the localization of upwelling-induced phytoplankton growth in a minor way. The model ecosystem assumes immediate response of biological production when upwelled water encounters light. However, a lag time of 1-2 days in phytoplankton growth has been reported for an upwelling ecosystem in the western North Pacific (Ishizaka et al., 1983). The lag time would allow for downstream displacement of chlorophyll. At the speed of $30 \mathrm{~cm} \mathrm{~s}^{-1}$, one day's lag corresponds to a travel distance of $26 \mathrm{~km}$.

\subsubsection{Region $V$ : east of Vietnam}

Fig. 11a shows intensive upwelling occurring along the shelf break to the southeast of Vietnam in summer. This upwelling is induced by the separation of the western boundary current from the Vietnam coast in summer (Figs. 1 and 11a). This type of upwelling is common in many parts of the ocean. In a larger scale setting, similar upwelling in the North Atlantic Ocean is also observed north of the latitude where the Gulf Stream separates from the coast near Cape Hatteras (Csanady and Hamilton, 1988). Upwelling occurs from April to September in the upwelling center $\mathrm{V}_{\mathrm{U}}$ (Fig. 12c).

The modeled mean chlorophyll concentration (Fig. 13b) reaches a primary peak of $0.9 \mathrm{mg} \mathrm{m}^{-3}$ in August and a secondary peak of $0.4 \mathrm{mg} \mathrm{m}^{-3}$ in December, with a rather low level (0.1$0.3 \mathrm{mg} \mathrm{m}^{-3}$ ) in between. The CZCS-SeaWiFS data follow a similar seasonal trend. The correlation is very good with $R^{2}$ value as high as 0.94 , but the ocean color-derived values reach only $44 \%$ of the modeled chlorophyll concentrations. There are no sea truth data available for validation. The modeled upwelling intensifies from June to August (Fig. 12c), whereas the phytoplankton blooms from July to September (Fig. 13b), lagging behind the intensification of upwelling by about a month.

In addition to the SeaWiFS image (Fig. 7a), there is other evidence to support summer upwelling off the eastern coast of Vietnam. Analyzing SST images from 1982 to 1992, Cong (1999) reported negative temperature anomalies in July and August along the Vietnam coast between $11^{\circ} \mathrm{N}$ and $13^{\circ} \mathrm{N}$. This area is the center of the modelpredicted high chlorophyll patch. Kuo et al. (2000) also reported cold water patches and filaments off 
the east coast of Vietnam in May, June and August, 1997.

The modeled chlorophyll distribution during upwelling off Vietnam (Fig. 7b) again shows a radial distribution similar to that off Luzon (Fig. 9b), whereas the SeaWiFS image (Fig. 7a) shows a narrower band extending seaward to the northeast. Kuo et al. (2000) reported filament-type structures of the upwelled waters off the southwest coast of Vietnam around $12^{\circ} \mathrm{N}$. Both the observed high chlorophyll bands and the low temperature filaments occur at the point where the western boundary current separates from the coastline as shown in Figs. 1 and 11a. Clearly the modeled flow field agrees with the observed surface features qualitatively, but the magnitude of the modeled advection is probably not sufficient to carry the upwelling water downstream far enough.

The weak chlorophyll peak in winter (Fig. 13b) is not driven by the local upwelling along the Vietnamese coast, because downwelling occurs in this area in winter according to the modeled vertical transport (Fig. 11b). Nevertheless upwelling occurs in the offshore area of the Vietnamese coast and results in modest chlorophyll rise. This weak offshore upwelling is related to the upwelling off the Sunda Shelf, which is to be discussed next.

\subsubsection{Region S: north of Sunda Shelf}

Based on the sea-surface temperature data set from the National Center for Environmental Prediction of the USA, Chu et al. (1997) reported a strong negative SST anomaly of $1.8-2.4^{\circ} \mathrm{C}$ off southeast Vietnam in winter months (DecemberFebruary). This strongly supports the upwelling scenario. The region is in low latitudes of diminishing Coriolis parameter. As the southward current in winter impinges on the shelf break to the north of Sunda Shelf, it is uplifted by the shoaling topography, inducing upwelling.

The model-predicted chlorophyll variation (Fig. 13c) is similar to that in Region L. The chlorophyll level reaches a winter peak of $0.65 \mathrm{mg} \mathrm{m}^{-3}$ in January and a weak summer peak of $0.18 \mathrm{mg} \mathrm{m}^{-3}$ in July. The CZCS-SeaWiFS data also show elevated chlorophyll values in winter, but the values are only $1 / 4-1 / 2$ of the modelpredicted values. From May to October, the

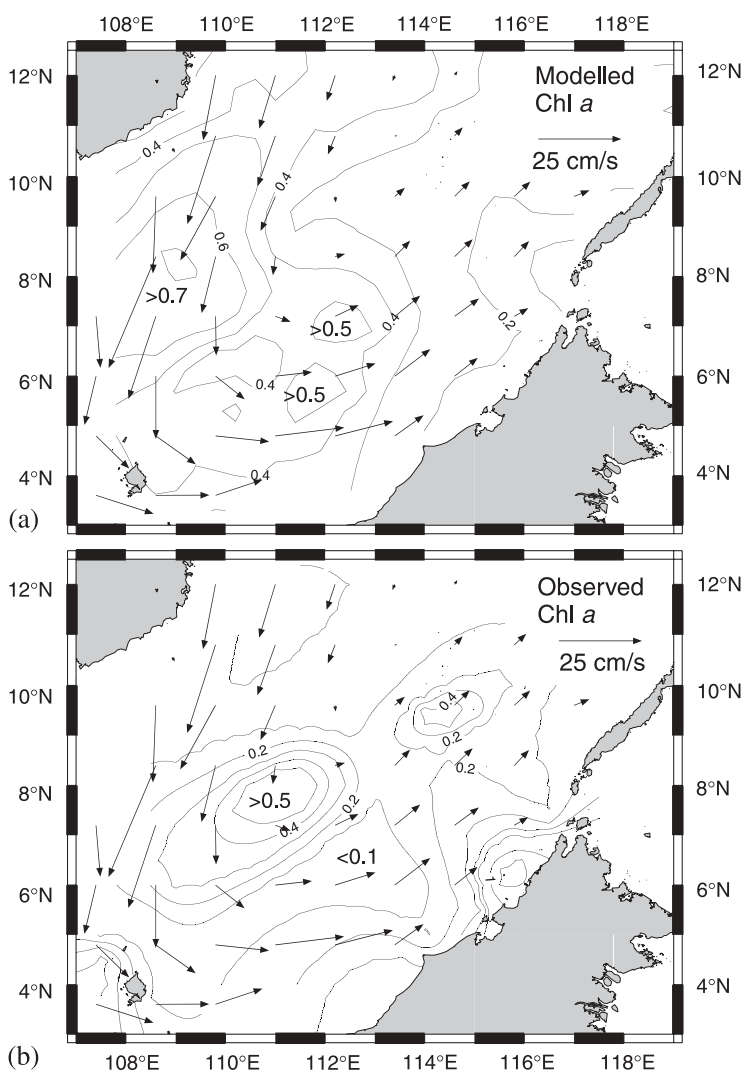

Fig. 15. Same as Fig. 14 except for southern SCS in December: (a) model results and (b) observations in December 1989 and December 1993 (Huang and Chen, 1997). The flow field is at $50 \mathrm{~m}$ depth for December. The strong counter-clockwise current may advect the upwelling water downstream.

modeled values are in reasonable agreement with the ocean color data. Shipboard observations (Huang and Chen, 1997) in Decembers of 1989 and 1993 in the southern SCS showed large patches of moderately elevated chlorophyll level (up to $0.7 \mathrm{mg} \mathrm{m}^{-3}$ ) in the region between Vietnam and Borneo (Fig. 15b). In Fig. 15b, the mean surface chlorophyll concentration in the region of elevated concentrations is $0.26 \mathrm{mg} \mathrm{m}^{-3}$, which is between the mean value $\left(0.19 \mathrm{mg} \mathrm{m}^{-3}\right)$ from ocean color and the modeled value $\left(0.56 \mathrm{mg} \mathrm{m}^{-3}\right)$. However, the high chlorophyll patches shift downstream from the upwelling center in ways similar to that off northwest Luzon (Fig. 14b), indicating again insufficient advective transport in the model. 
The winter upwelling flux of DIN in this region (Fig. 12d) reaches the highest level $(14 \mathrm{mmol}$ $\mathrm{N} \mathrm{m}^{-2} \mathrm{~d}^{-1}$ ) among the three regions, but the chlorophyll levels in winter from shipboard observations or ocean color data (Fig. 13c) are not very high compared to other upwelling regions. Fig. $11 \mathrm{~b}$ shows a rather extensive zone of strong upwelling in the southern end of the central basin, which is bordered by strips of strong downwelling near shelf breaks to the west and south. A considerable fraction of the upwelled nitrate must have been returned to the deep water by downwelling. The weak chlorophyll peak in summer (Fig. 13c) is likely a result of the narrow upwelling band at the shelf edge of the Sunda Shelf (Fig. 11a).

\subsubsection{Outside upwelling regions}

Outside the three upwelling regions, the model still predicts significant seasonality in chlorophyll concentration. An example is given at Site S1 (Fig. 13d), where the seasonal trend follows that in Region $\mathrm{L}$ but is much reduced in magnitude. The model matches the CZCS-SeaWiFS data reasonably well from January to October but overestimates considerably in November and December. Although both modeled values and CZCS-SeaWiFS data demonstrate winter-summer contrast, in situ time-series data do not show a clear seasonal trend. Leaving seasonality aside, all three sets of data fall within a similar range of chlorophyll concentrations. The mean value for the shipboard data is $0.15 \mathrm{mg} \mathrm{m}^{-3}$, which is closely matched by the modeled mean $\left(0.16 \mathrm{mg} \mathrm{m}^{-3}\right)$. The mean $\left(0.12 \mathrm{mg} \mathrm{m}^{-3}\right)$ from CZCS-SeaWiFS data is a little lower. The lack of seasonality in the measured data suggests that processes other than monsoon forcing, such as mesoscale eddies, are at least equally important in controlling the chlorophyll concentration outside upwelling regions. These processes apparently operate at higher frequencies and, when averaged over longer terms, their signals tend to be averaged out. This explains why the monthly composites of CZCS data have retained a clear winter-summer contrast (Fig. 13d). The numerical model, on the other hand, does not contain enough horizontal resolu- tion to produce mesoscale eddies, and, therefore, also retains a strong seasonal variation.

\subsection{Primary productivity, grazing and export detritus flux}

Chlorophyll and primary production were measured at six stations $\left(17.9-22.3^{\circ} \mathrm{N}, 115.5-\right.$ $119.8^{\circ} \mathrm{E}$ ) on OR-I Cruise 575 in the northern SCS in March 2000. Fig. 16 shows measured and modeled profiles of (a) nitrate (plus nitrite), (b) chlorophyll and (c) primary production (G.-C. Gong, unpublished data; Chen, 2000) at Site C $\left(18.0^{\circ} \mathrm{N}, 115.5^{\circ} \mathrm{E}\right)$, which was near Site S1. Similar to those shown in Fig. 4, the observed chlorophyll profile at Site C (Fig. 16b) shows a strong SCM $\left(0.47 \mathrm{mg} \mathrm{m}^{-3}\right)$, three times the surface concentration $\left(0.15 \mathrm{mg} \mathrm{m}^{-3}\right)$. The depth of the SCM was at $60 \mathrm{~m}$, corresponding to the nitracline. The primary production profile (Fig. 16c) also showed a local maximum at the same depth, which was $40 \%$ of the surface value. The significant primary productivity associated with the SCM demonstrates the vitality of the deep dwelling phytoplankton.

The modeled chlorophyll profile (Fig. 16b) compares favorably with the observed profile. The surface value $\left(0.12 \mathrm{mg} \mathrm{m}^{-3}\right)$ is slightly lower than the observed value. The peak value at the SCM of $0.45 \mathrm{mg} \mathrm{m}^{-3}$ is almost the same as the observed value. The depth of the SCM $(50 \mathrm{~m})$ is $10 \mathrm{~m}$ shallower than that observed. The modeled nitracline (Fig. 16a) is also shallower, accounting for the upward displacement of SCM in the model. Other than the nitracline layer $(30-70 \mathrm{~m})$, the modeled DIN concentrations are in good agreement with observed values. It is noted that the modeled DIN includes all species of inorganic fixed nitrogen, including ammonia, which could be relatively important above the nitracline. The observed $\left[\mathrm{NO}_{3}^{-}+\mathrm{NO}_{2}^{-}\right]$concentration should be considered as the lower limit for DIN in the surface layer. It is also noted that the modeled chlorophyll concentration (Fig. 16b) below the SCM diminishes sharply, but the observed decreasing trend is more gradual. Although the photoadaptive scheme (Doney et al., 1996) is employed for the phytoplankton growth, the model is still unable to produce the significant 


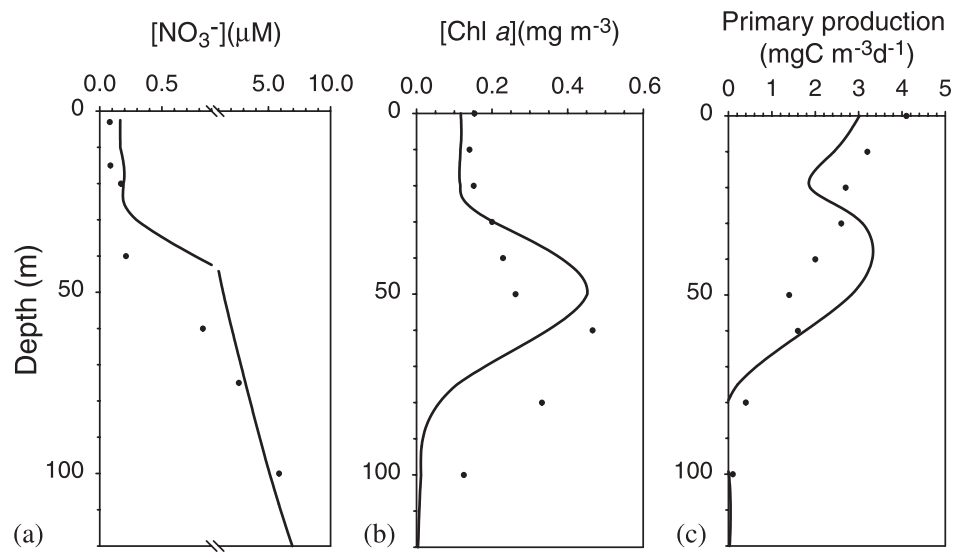

Fig. 16. Observed values (dots) of (a) $\left[\mathrm{NO}_{3}^{-}+\mathrm{NO}_{2}^{-}\right]$, (b) chlorophyll, and (c) primary production from $\mathrm{Site} \mathrm{C}\left(18.0^{\circ} \mathrm{N}, 115.5^{\circ} \mathrm{E}\right)$ near Site S1 (see Fig. 1) in March 2000 and corresponding modeled profiles (curves) for March at the same site. Note that the scale for nitrate is expanded in the first $1 \mu \mathrm{M}$ (see text). The model successfully produces a strong SCM, but its peak depth is shallower than the observed. The shallower SCM also occurs elsewhere in the model. The model underestimates both the chlorophyll level and primary production in the surface layer by about $25 \%$ and also in the deeper water $(>60 \mathrm{~m})$. Nevertheless, the depth-integrated primary production of the model output $\left(176 \mathrm{mg} \mathrm{C} \mathrm{m}^{-2} \mathrm{~d}^{-1}\right)$ matches that of the observed value $\left(175 \mathrm{mg} \mathrm{Cm}^{-2} \mathrm{~d}^{-1}\right)$ well.

deep chlorophyll below the SCM. This warrants an in-depth investigation to study the viability and the photoadaptive properties of the observed deep dwelling pico-eukaryotes (H.B. Liu, personal communication).

The modeled primary production in units of $\mathrm{mg}$ $\mathrm{C} \mathrm{m}^{-3} \mathrm{~d}^{-1}$ is calculated by multiplying the nitrogen-based phytoplankton growth rate with the $C / N$ ratio of 6.63 (Redfield et al., 1963). The phytoplankton growth rate, represented by the first term on the right-hand side of Eq. (2), was integrated in time and then averaged every 10 days during the model run. The modeled profile of primary production at Site $\mathrm{S} 1$ is illustrated in Fig. 16c. The model underestimates the surface primary production, but overestimates the contribution from the SCM. The underestimation in the surface water apparently results from slightly underpredicted surface chlorophyll values from the model (Fig. 16b). In addition, the modeled incident light intensity is lower than the observed solar irradiance in the reported case. The overestimation in the subsurface layer is a result not only of the overestimated chlorophyll between 30 and $60 \mathrm{~m}$, but also of the elevated nitracline in the model. The predicted DIN at $40 \mathrm{~m}$ is $0.7 \mu \mathrm{M}$, which results in a $78 \%$ DIN saturation instead of the $50 \%$ saturation as implied by the observed concentration of $0.2 \mu \mathrm{M}$. Leaving depth-dependent discrepancies aside, the depth-integrated primary production (IPP) from the model $\left(176 \mathrm{mg} \mathrm{C} \mathrm{m}^{-2} \mathrm{~d}^{-}\right.$ $\left.{ }^{1}\right)$ matches the observed value $\left(175 \mathrm{mg} \mathrm{C} \mathrm{m}^{-2} \mathrm{~d}^{-1}\right)$ rather well. Over the six stations in the northern SCS, the average of the measured IPP was $313 \mathrm{mg}$ $\mathrm{C} \mathrm{m}^{-2} \mathrm{~d}^{-1}$ (G.-C. Gong, unpublished data), and the mean of the modeled values is $363 \mathrm{mg}$ $\mathrm{C} \mathrm{m}^{-2} \mathrm{~d}^{-1}$, which is in reasonable agreement with the observed value.

Averaging over the entire basin area, Fig. 17 shows the annual variation of IPP, integrated grazing pressure and downward flux of particulate organic carbon (POC) at $125 \mathrm{~m}$ depth. The mean depth-integrated primary production over the entire output domain follows the seasonal variation of chlorophyll, with high values in winter and summer and low values in between (Fig. 17). It varies between 207 and $373 \mathrm{mg} \mathrm{C} \mathrm{m}^{-2} \mathrm{~d}^{-1}$ with an annual mean of $280 \mathrm{mg} \mathrm{Cm}^{-2} \mathrm{~d}^{-1}$. The highest productivity is in February; the summer peak is considerably lower, just about the same as the annual mean level.

The modeled annual mean is similar to that (290 $\mathrm{mg} \mathrm{C} \mathrm{m}^{-2} \mathrm{~d}^{-1}$ ) estimated for the Indian Ocean monsoon gyres (Longhurst et al., 1995). 


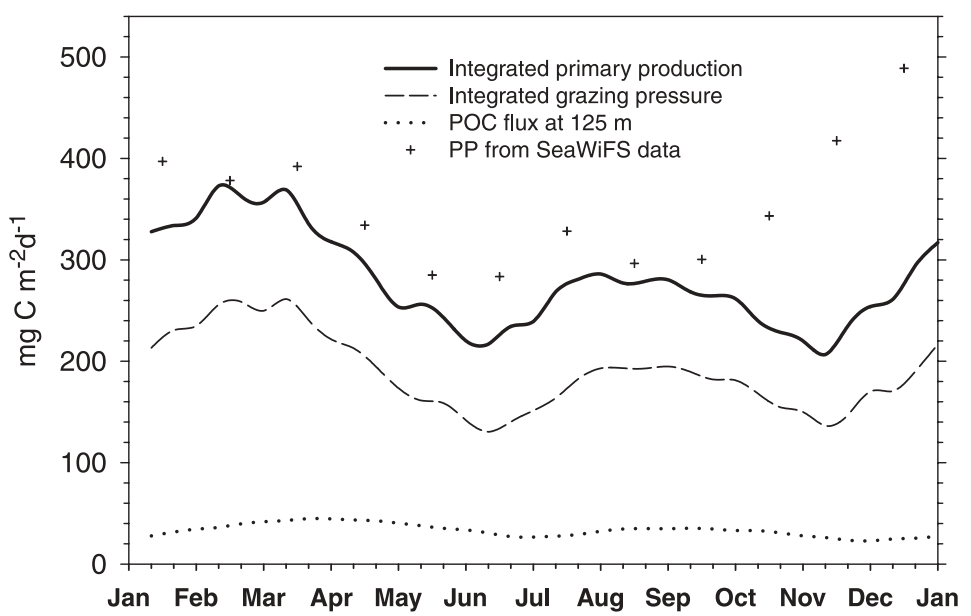

Fig. 17. Annual variation of basin-wide averages of depth-integrated values of primary production and grazing for the top $135 \mathrm{~m}$ of the basin and area-averaged export flux of POC at $125 \mathrm{~m}$ in the SCS. The time series are model outputs at 10-day intervals. For comparison are the primary productivity data (crosses) derived from SeaWiFS data (see text).

We also calculated the monthly mean values over the model output domain from the global primary productivity data set provided by the Ocean Primary Productivity Research Team at the Institute of Marine and Coastal Sciences, Rutgers University (http://marine.rutgers.edu/opp). The data set at $0.5^{\circ}$ resolution was derived from SeaWiFS ocean color images and the semianalytical model of Behrenfeld and Falkowsky (1997). The monthly mean primary productivity values are also shown in Fig. 17. They all are higher than the modeled values. Nevertheless, the SeaWiFS-derived values also show a strong winter peak and a weak summer peak, and the modeled values from January to September follow a similar variation reasonably well. The SeaWiFS-derived value increases markedly in October and continues to rise in November and December. The annual mean of the SeaWiFS-derived values is $354 \mathrm{mg}$ $\mathrm{C} \mathrm{m}^{-2} \mathrm{~d}^{-1}$, which is $20 \%$ higher than the modeled value. For the first 9 months, the discrepancy is reduced to $14 \%$.

The zooplankton grazing rate is calculated in the same way as the phytoplankton growth rate. Concurrently, the export flux of detritus from the euphotic zone is calculated at each horizontal grid point by multiplying the modeled detritus concentration at $125 \mathrm{~m}$ depth with the net downward velocity $\left(-W_{D}\right)$ of the detritus. The grazing pressure and the detritus sinking flux are also converted to carbon units in Fig. 17. The particle fluxes in the northern SCS were observed with sediment traps deployed at a station $\left(18.47^{\circ} \mathrm{N}\right.$, $116.02^{\circ} \mathrm{E}$ ) near Site $\mathrm{S} 1$. The shallowest trap was deployed at $1000 \mathrm{~m}$ from September 1987 to March 1988. The mean of measured POC fluxes was $5.6 \mathrm{mg} \mathrm{m}^{-2} \mathrm{~d}^{-1}$ (Jennerjahn et al., 1992). Using the normalized depth-dependent function of POC flux observed near Hawaii (Martin et al., 1987), we back-calculated the expected POC flux at $125 \mathrm{~m}$ to be $42 \mathrm{mg} \mathrm{m}^{-2} \mathrm{~d}^{-1}$. The modeled mean flux at $125 \mathrm{~m}$ depth from the same area from September to March is $48 \mathrm{mg} \mathrm{m}^{-2} \mathrm{~d}^{-1}$, which is close to the back-calculated POC flux, suggesting that the model is doing a reasonable job in simulating the POC flux.

The modeled sinking flux of POC at $125 \mathrm{~m}$ shows an annual cycle similar to that of the primary production, but its peaks lag behind the primary production peaks by about half a month. The model predicts that, on average, $70 \%$ of the primary production is removed by zooplankton grazing and the other $30 \%$ by phytoplankton decay and aggregation (Fig. 17). The exported POC to the deeper water below the euphotic zone represents $8-16 \%$ of the primary production with 

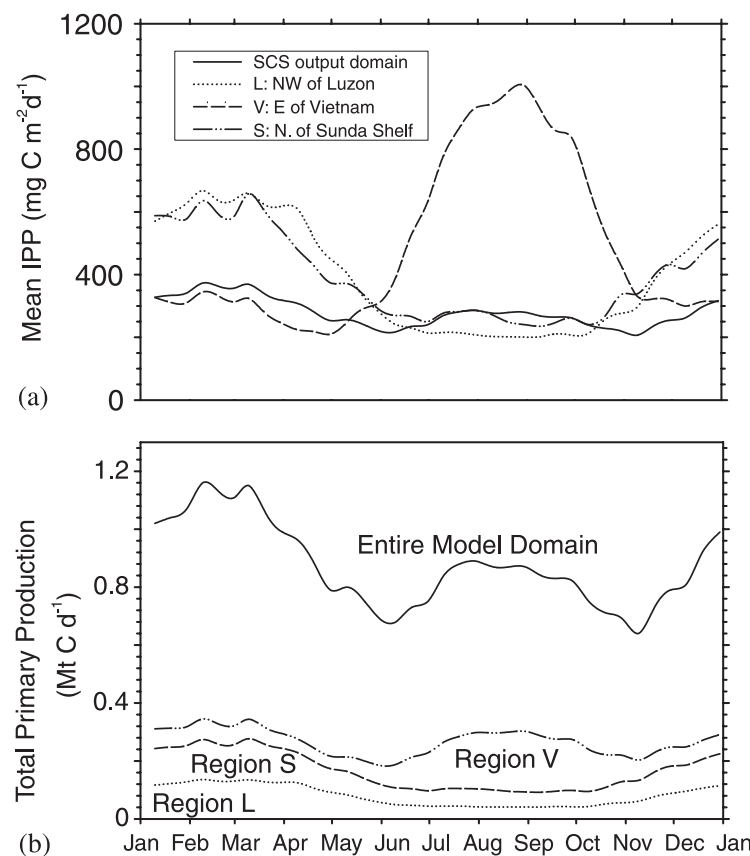

(b)

Fig. 18. (a) Annual variation of area-averaged IPP in the three upwelling regions and the whole output domain for the top $135 \mathrm{~m}$. Time series are model outputs at 10-day intervals. (b) Corresponding volume-integrated primary production in the three upwelling regions and the entire basin.

a mean value of $12 \%$, which may be considered as the mean $f$-ratio of the SCS. In the three upwelling regions, the sinking detritus accounts for only about $1 / 3$ of the upwelled DIN, indicating that $2 / 3$ of the upwelled DIN must have been dispersed out of upwelling regions. This supports the notion that the upwelling regions are major sources of new nutrients to the upper water column in the SCS (Shaw et al., 1996).

Fig. 18 shows similar area averages of IPP (top panel) and total primary production (bottom panel) for the entire basin as well as in the three upwelling areas (L, V and S in Fig. 10). The three upwelling regions have roughly the same areas $\left(2.04-2.16 \times 10^{6} \mathrm{~km}^{2}\right)$, each about $7 \%$ of the total area of the output domain. The volume-integrated primary production (Fig. 18b) shows that the three regions (L, V, and $\mathrm{S}$ ) produce, respectively, 29, 40 and $31 \mathrm{Mt}$ of phytoplankton carbon annually; altogether they account for $30 \%$ of basin-wide total primary production. In Fig. 18a, the mean IPP for Regions $\mathrm{L}$ and $\mathrm{S}$ reaches maximum (around $650 \mathrm{mg} \mathrm{C} \mathrm{m}^{-2} \mathrm{~d}^{-1}$ ) in January and February, whereas that for Region V reaches $1000 \mathrm{mg}$ $\mathrm{C} \mathrm{m}^{-2} \mathrm{~d}^{-1}$ in August. These peak IPP values are much higher than basin averages.

\section{Conclusions}

Biogeochemical observations clearly demonstrated a sharp contrast between the SCS and the western Philippine Sea. In addition to the uplifted nutricline in the SCS, which was previously reported (Gong et al., 1992), we demonstrate the surface chlorophyll level in the SCS to be about twice that in the western Philippine Sea. Ocean color images show strong seasonal changes of phytoplankton distribution in the SCS. The monsoon-forced model has succeeded in maintaining the uplifted nitracline and generating the observed level of chlorophyll in the SCS. The model also successfully produces the main features in the spatial and temporal patterns of chlorophyll variation, such as the patches of high chlorophyll in upwelling regions northwest of Luzon and north of Sunda Shelf in winter and off the east coast of Vietnam in summer. The model predicts a strong subsurface chlorophyll maximum, but its depth is shallower than what was observed. The modeled primary production gives a basin-wide annual average IPP of $280 \mathrm{mg} \mathrm{C} \mathrm{m}^{-2} \mathrm{~d}^{-1}$, which is about $80 \%$ of the mean value derived from the SeaWiFS data ( $354 \mathrm{mg} \mathrm{C} \mathrm{m}^{-2} \mathrm{~d}^{-1}$ ). Nevertheless, the modeled temporal variation of primary production is similar to the SeaWiFS-derived trend with a strong winter peak and a weak summer peak. The modeled POC flux at $125 \mathrm{~m}$ appears to be reasonable as compared to the value based on one sediment trap observation. The mean export fraction of primary production or the $f$-ratio predicted by the model is 0.12 .

In biogeochemical modeling, the profound difficulty in matching the model with observations in the four-dimensional realm should be emphasized. Even if a one-dimensional (vertical) model is perfectly tuned, its application in the four-dimensional space is likely to produce visible 
discrepancies. Possible sources of discrepancies include the inadequate resolution in the physical and biogeochemical components of the model, and inadequate data coverage needed to improve surface forcing and open-ocean boundary conditions. Despite these deficiencies, the model reproduces temporal and spatial distribution patterns of biogeochemical variables rather well, although the quantitative aspects of the model performance are still in need of improvements.

One major discrepancy between model results and observations is the insufficient dispersion of high chlorophyll patches from the upwelling centers. Another discrepancy is the overestimation of shallow chlorophyll and underestimation of deep chlorophyll. Possible causes lie in both insufficient data to properly constrain boundary conditions for DIN and the modeling schemes of hydrodynamics and biogeochemistry. More surveys in the western Philippine Sea near the Luzon Strait are required to better define the boundary conditions for DIN. A more refined lateral resolution and more realistic wind field should be used to improve the hydrodynamic model. Better understanding of photoadaptation of the deepdwelling phytoplankton is required to improve the biogeochemical scheme. Future observations of the grazing pressure and the export fraction of detritus from the euphotic zone are needed for validation of model processes related to grazing, particle aggregation and sinking of detritus.

\section{Acknowledgements}

We are grateful for the thorough and critical reviews by two anonymous reviewers. Dr. C.-R. $\mathrm{Wu}$ assisted in preparing various files for the numerical model. Drs. M.-A. Lee and I.-I. Lin, Magi Lian and J.H. Tai assisted in processing satellite and ADCP data. This work was supported by Grant NSC89-2611-M002-037-OP1 to KKL from the National Science Council of the Republic of China. It was also supported by an NSC scholarship, \#36129F, and by the Horn Point Laboratory, University of Maryland Center for Environmental Science, during KKL's sabbatical leave in 1997-1998. This is National Center for Ocean Research Contribution No. 55.

\section{References}

Bannister, T.T., 1974. Production equations in terms of chlorophyll concentration, quantum yield, and upper limit to production. Limnology and Oceanography 19, 1-12.

Behrenfeld, M.J., Falkowsky, P.G., 1997. Photosynthetic rates derived from satellite-based chlorophyll concentrations. Limnology and Oceanography 42, 1-20.

Bernhardt, F., Philippes, H., 1958. Die räumliche und zeiliche Verteilung der Einstrahlung, der Ausstraulung, und der Straulungsbilanz im Meeresnivean. I. Die Einstrahlung. Abhandlungen Meteorl. Hydrol. Dienst. DDR, No. 45, Akademie-Verlag, Berlin, 227pp.

Blough, N.V., Zafiriou, O.C., Bonilla, J., 1993. Optical absorption spectra from the Orinoco River outflow: terrestrial input of colored organic matter to the Caribbean. Journal of Geophysical Research 98, 2271-2278.

Broecker, W.S., Patzert, W.C., Toggweiler, J.R., Stuiver, M., 1986. Hydrography, chemistry and radioisotopes in the south-east Asian basins. Journal of Geophysical Research 91, 14345-14354.

Burkill, P.H., 1999. Arabesque: an overview. Deep-Sea Research II 46, 529-547.

Carder, K.L., Steward, R.G., Paul, J.H., Vargo, G.A., 1986. Relationships between chlorophyll and ocean color constituents as they affect remote-sensing reflectance models. Limnology and Oceanography 31, 403-413.

Chao, S.Y., Kao, T.W., Al-Hajri, K.R., 1992. A numerical investigation of circulation in the Arabian Gulf. Journal of Geophysical Research 97, 11219-11236.

Chao, S.Y., Shaw, P.T., Wu, S.Y., 1996a. Deep water ventilation in the South China Sea. Deep-Sea Research I 43, 445-466.

Chao, S.Y., Shaw, P.T., Wu, S.Y., 1996b. El Niño modulation of the South China Sea circulation. Progress in Oceanography $38,51-93$.

Chen, C.T.A., Wang, S.L., 1998. Influence of intermediate water in the western Okinawa Tough by the outflow from the South China Sea. Journal of Geophysical Research 103, 12683-12688

Chen, M.T., Beaufort, L., the Shipboard Scientific Party of the IMAGES III/MD106-IPHIS Cruise (Leg II), 1998. Exploring Quaternary variability of the East Asia monsoon, Kuroshio Current, and Western Pacific warm pool systems: high-resolution investigations of paleoceanography from the IMAGES III (MD106)-IPHIS Cruise. Terrestrial Atmospheric Oceanic Sciences 9, 129-142.

Chen, Y.L.L., 2000. A study of relationships among water mixing, nutrients, nitrate uptake and phytoplankton sizes in the South China Sea. In: Proceedings of the Workshop for NSC Oceanographic Research Programs-2000, National Science Council, Taiwan, Republic of China, pp. 169-172. 
Chu, P.C., Lu, S., Chen, Y., 1997. Temporal and spatial variability of the South China Sea surface temperature anomaly. Journal of Geophysical Research 102, 2093720955.

Cong, N.T., 1999. Characteristics of sea surface temperature of eastern Vietnam Sea. Eos, Transactions, American Geophysical Union 80, S189.

Conkright, M.E., Levitus, S., Boyer, T.P., 1994. World Ocean Atlas 1994, Volume 1: Nutrients. NOAA Atlas NESDIS 1. US Printing Office, Washington, DC, $162 \mathrm{pp}$.

Csanady, G.T., Hamilton, P., 1988. Circulation of slope water. Continental Shelf Research 8, 565-624.

Doney, S.C., Glover, D.M., Najjar, R.R., 1996. A new coupled, one-dimensional biological-physical model for the upper ocean: application to the JGOFS Bermuda Atlantic Time-series Study (BATS) site. Deep-Sea Research II 43, 591-624.

Evans, G.T., Garçon, V.C. (Eds.), 1997. One-dimensional models of water column biogeochemistry. JGOFS Report No. 23/97, JGOFS, Bergen, Norway, 85pp.

Fasham, M.J.R., Ducklow, H.W., McKelvie, S.M., 1990. A nitrogen-based model of plankton dynamics in the oceanic mixed layer. Journal of Marine Research 48, 591-639.

Feldman, G.C., Kuring, N., Ng, C., Esaias, W., McClain, C., Elrod, J., Maynard, N., Endres, D., 1989. Ocean coloravailability of the global data set. Eos, Transactions, American Geophysical Union 70, 634.

Furuya, K., 1990. Subsurface chlorophyll maximum in the tropical and subtropical western Pacific Ocean: vertical profiles of phytoplnakton biomass and its relationship with chlorophyll a and particulate organic carbon. Marine Biology 107, 529-539.

Gong, G.-C., 1992. Chemical hydrography of the Kuroshio front in the sea north-east of Taiwan. Ph.D. Dissertation, Institute of Oceanography, National Taiwan University, 204pp.

Gong, G.-C., Liu, K.-K., Liu, C.-T., Pai, S.-C., 1992. Chemical hydrography of the South China Sea and a comparison with the West Philippine Sea. Terrestrial Atmospheric Oceanic Sciences 3, 587-602.

Gong, G.-C., Yang, W.-R., Wen, Y.H., 1993. Correlation of chlorophyll $a$ concentration and Sea Tech fluorometer fluorescence in seawater. Acta Oceanographica Taiwanica $31,117-125$.

Gong, G.-C., Wen, Y.-H., Schieber, B.D., 1998. Absorption coefficient of colored dissolved organic matter and its effect on the SeaWiFS chlorophyll value in the East China Sea in winter. Eos, Transactions, American Geophysical Union 79, W42.

Gong, G.-C., Chang, J., Wen, W.-H., 1999. Estimation of annual primary production in the Kuroshio waters northeast of Taiwan using a photosynthesis-irradiance model. Deep-Sea Research 46, 93-108.

Gregg, W.W., Conkright, M.E., 2001. Global seasonal climatologies of ocean chlorophyll: blending in situ and satellite data for the CZCS era. Journal of Geophysical Research 106 (C2), 2499-2515.
Huang, L., Chen, C., 1997. Distribution of chlorophyll $a$ and primary productivity of Nansha Islands sea area in winter. In: Huang, L. (Ed.), A Study on Ecological Processes of Nansha Islands Sea Area (I). Science Press, Beijing, pp. 115.

Huang, C.Y., Wu, S.F., Zhao, M., Chen, M.T., Wang, C.H., Tu, X., Yuan, P.B., 1997. Surface ocean and monsoon climate variability in the South China Sea since the last glaciation. Marine Micropaleontology 32, 71-94.

IOCCG, 2000. Remote sensing of ocean color in coastal, and other optically-complex, waters. In: Sathyendranath, S. (Ed.), Reports of the International Ocean-Color Coordinating Group, No. 3, IOCCG, Dartmouth, Canada.

Ishizaka, J., Takahashi, M., Ichimura, S., 1983. Evaluation of coastal upwelling effects on phytoplankton growth by simulated culture experiments. Marine Biology 76, 271-278.

Jassby, A.D., Platt, T., 1976. Mathematical formulation of the relationship between photosynthesis and light for phytoplankton. Limnology and Oceanography 21, 540-547.

Jennerjahn, T.C., Liebezeit, G., Kempe, S., Xu, L.Q., Chen, W.B., Wong, H.K., 1992. Particle flux in the northern South China Sea. In: Jin, X., Kudrass, H.R., Pautot, G. (Eds.), Marine Geology and Geophysics of the South China Sea. China Ocean Press, China, pp. 228-235.

Kalnay, E., Kanamitsu, M., Kistler, R., Collins, W., Deaven, D., Gandin, L., Iredell, M., Saha, S., White, G., Woollen, J., Zhu, Y., Chelliah, M., Ebisuzaki, W., Higgins, W., Janowiak, J., Mo, K.C., Ropelewski, C., Wang, J., Leetmaa, A., Reynolds, R., Jenne, R., Joseph, D., 1996. The NCEP/NCAR 40-year reanalysis project. Bulletin American Meteorological Society 77, 437-471.

Kuo, N.J., Zheng, Q., Ho, C.R., 2000. Satellite observation of upwelling along the western coast of the South China Sea. Remote Sensing of Environment 74, 463-470.

Levitus, S., 1982. Climatological atlas of the world ocean. NOAA Professional Paper No. 13, US Government Printing Office, Washington, DC, 173pp.

Longhurst, A.R., Sathyendranath, S., Platt, T., Caverhill, C., 1995. An estimation of global primary production in the ocean from satellite radiometer data. Journal of Planktonic Research 17, 1245-1271.

Loukos, H., Frost, B., Harrison, D.E., Murray, J.W., 1997. Ecosystem model with iron limitation of primary production in the equatorial pacific region. Deep-Sea Research II 44, 2221-2249.

Martin, J.H., Knauer, G.A., Karl, D.M., Broenkow, W.W., 1987. VERTEX: carbon cycling in the north Pacific. DeepSea Research 34, 267-285.

McGillicuddy, D.J., McCarthy, J.J., Robinson, A.R., 1995. Coupled physical and biological modeling of the spring bloom in the North Atlantic (I): model formulation and one-dimensional bloom processes. Deep-Sea Research I 42, 1313-1357.

Milliman, J.D., Rutkowski, C., Meybeck, M., 1995. River discharge to the sea: a global river index. LOICZ Reports and Studies. LOICZ, Texel, The Netherlands, 125pp. 
Nitani, H., 1972. Beginning of the Kuroshio. In: Stommel, H., Yoshida, K. (Eds.), Kuroshio. University of Washington Press, Seattle, pp. 129-163.

Ose, T., Song, Y.K., Kitoh, A., 1997. Sea surface temperature in the South China Sea - an index for the Asian monsoon and ENSO system. Journal of Meteorological Society of Japan 75, 1091-1107.

Parsons, T.R., Maita, Y., Lalli, C.M., 1984. A Manual of Chemical and Biological Methods for Seawater Analysis. Pergamon Press, New York.

Prell, W.L., Wang, P., Blum, P., 1999. Ocean Drilling Program Leg 184 Preliminary Report: South China Sea. Texas A\&M University, College Station, TX.

Redfield, A.C., Ketchum, B.H., Richards, F.A., 1963. The influence of organisms on the compositions of sea-water. In: Hill, M.N. (Ed.), The Sea, Vol. 2. Interscience Publishers, New York, pp. 26-77.

Sarmiento, J.L., Slater, R.D., Fasham, M.J.R., Ducklow, H.W., Toggweiler, J.R., Evans, G.T., 1993. A seasonal three-dimensional ecosystem model of nitrogen cycling in the North Atlantic euphotic zone. Global Biogeochemical Cycle 7, 417-450.

Semtner, A.J., 1974. An oceanic general circulation model with bottom topography. Technical Report 9, Department of Meteorology, University of California, Los Angeles, 99pp.

Shaw, P.-T., Chao, S.-Y., 1994. Surface circulation in the South China Sea. Deep-Sea Research I 41, 1663-1683.

Shaw, P.-T., Chao, S.-Y., Liu, K.-K., Pai, S.-C., Liu, C.-T., 1996. Winter upwelling off Luzon in the north-eastern South China Sea. Journal of Geophysical Research 101, 16435-16448.

Shiah, F.-K., Liu, K.-K., Tang, T.Y., 1999. South East Asia Time-series Station established in South China Sea. US JGOFS Newsletter 10 (1), 8-9.

Smith, S.L., Codispoti, L.A., Morrison, J.M., Barber, R.T., 1998. The 1994-96 Arabian expedition: an integrated, interdisciplinary investigation of the response of the northwestern Indian Ocean to monsoonal forcing. Deep-Sea Research II 45, 1905-1915.

Strickland, J.D.H., Parsons, T.R., 1972. A Practical Handbook of Seawater Analysis. Fisheries Research Board of Canada, Ottawa, Canada, 310pp.

Sverdrup, H.U., Johnson, M.W., Fleming, R.H., 1942. The Oceans. Prentice Hall, New York. 1087pp.
Tang, D.-L., Ni, I.-H., Kester, D.R., Muller-Karger, F.E., 1999. Remote sensing observations of winter phytoplankton blooms of the Luzon Strait in the South China Sea. Marine Ecology Progress Series 191, 43-51.

Torrance, K.E., Rockett, J.A., 1969. Numerical study of natural convection in an enclosure with localized heating from below-creeping flow to the onset of laminar instability. Journal of Fluid Mechanics 36 (part 1), 33-54.

Udarbe-Walker, M.J.B., Villanoy, C.L., 2001. Structure of potential upwelling areas in the Philippines. Deep-Sea Research I 48, 1499-1518.

Wang, L., Wang, P., 1990. Late Quaternary paleoceanography of the South China Sea: glacial interglacial contrasts in an enclosed basin. Paleoceanography 5, 77-90.

Wang, P., Wang, L., Bian, Y., Jian, Z., 1995. Late Quaternary paleoceanography of the South China Sea: surface circulation and carbonate cycles. Marine Geology 127, 145-165.

Wang, L., Sarnthein, M., Erlenkeuser, H., Grimalt, J., Grootes, P., Heilig, S., Ivanova, E., Kienast, M., Pelejero, C., Pflaumann, U., 1999. East Asian monsoon climate during the late Pleistocene: high-resolution sediment records from the South China Sea. Marine Geology 156, 245-284.

Wu, C.-R., Shaw, P.-T., Chao, S.-Y., 1999. Assimilating altimeter data into a South China Sea model. Journal of Geophysical Research 104, 29987-30005.

Wolanski, E., Nguyen, N.H., Le, T.D., Nguyen, H.N., Nguyen, N.T., 1996. Fine-sediment dynamics in the Mekong River Estuary, Vietnam. Estuarine Coastal Shelf Science 43, 565582.

Wyrtki, K., 1961. Physical oceanography of the south-east Asian waters. NAGA Report Vol. 2, Scientific Results of Marine Investigations of the South China Sea and the Gulf of Thailand. Scripps Institution of Oceanography, La Jolla, CA, 195pp.

Yang, W.R., 1995. Chemical hydrography, chlorophyll and primary productivity in the tropical western Pacific Ocean. M.S. Thesis, National Taiwan Ocean University, Keelung, Taiwan, 86pp.

Zhang, J., 1996. Nutrient elements in large Chinese estuaries. Continental Shelf Research 16, 1023-1045.

Zhang, Y., Sperber, K.R., Boyle, J.S., 1997. Climatology and interannual variation of the East Asian winter monsoon: results from the 1979-95 NCEP/NCAR reanalysis. Monthly Weather Review 125, 2605-2619. 